\title{
Sex and gonadal hormones in mouse models of Alzheimer's disease: what is relevant to the human condition?
}

\author{
Dena B Dubal", Lauren Broestl and Kurtresha Worden
}

\begin{abstract}
Biologic sex and gonadal hormones matter in human aging and diseases of aging such as Alzheimer's - and the importance of studying their influences relates directly to human health. The goal of this article is to review the literature to date on sex and hormones in mouse models of Alzheimer's disease (AD) with an exclusive focus on interpreting the relevance of findings to the human condition. To this end, we highlight advances in AD and in sex and hormone biology, discuss what these advances mean for merging the two fields, review the current mouse model literature, raise major unresolved questions, and offer a research framework that incorporates human reproductive aging for future studies aimed at translational discoveries in this important area. Unraveling human relevant pathways in sex and hormone-based biology may ultimately pave the way to novel and urgently needed treatments for $A D$ and other neurodegenerative diseases.
\end{abstract}

Keywords: Sex, Gender, Brain, Alzheimer's disease, A $\beta$, Tau, Neurodegeneration, Sex chromosomes, Hormones, Estrogen, Progesterone, Testosterone, Androgens, Cognition, Behavior, Pathology, Transgenic, Mouse, Human, Aging, Reproductive aging, Menopause, Andropause

\section{Introduction}

Biologic sex and gonadal hormones exert profound effects on brain function - and we are only beginning to appreciate the complexities of their actions in Alzheimer's disease $(\mathrm{AD})$ from studies of humans and mouse models. In 2010, the Institute of Medicine advocated for expansion of neuroscience research to understand sex differences in the susceptibility and progression of key neurodegenerative conditions such as AD [1]. Indeed, the importance of delineating sex- and hormone-based actions in $\mathrm{AD}$ cannot be underestimated for many reasons. First, $\mathrm{AD}$ is a tragic disease and the most common neurodegenerative condition, characterized by an insidious and progressive loss of memory and other cognitive functions. Second, true sex-based differences in AD exist. Thus, a more clear understanding of the exact nature of the sexual dimorphisms can shed light on what

\footnotetext{
* Correspondence: dena.dubal@ucsf.edu

Laboratory of Neuroscience and Aging Research, Department of Neurology, Sandler Neurosciences Center, Room 212B, University of California, San Francisco, San Francisco, CA 94158, USA
}

protects one sex or makes the other more vulnerable. Third, AD develops in an aging brain and a fundamental aspect of human aging is gonadal steroid depletion. Whether and how depletion of certain androgens in men and estrogens and progestins in women can affect brain health and vulnerability to $\mathrm{AD}$ emerge as highly relevant, and still unanswered, clinical questions. Finally, sex- and hormone-based actions in human $\mathrm{AD}$ lay the groundwork for the intelligent design, execution, and interpretation of studies in animal models of aging and AD. Ultimately, animal models of aging and disease enable rigorous dissection and mechanistic delineation that may pave the way to novel and urgently needed treatments to defeat $\mathrm{AD}$.

In this Review, we highlight advances in $\mathrm{AD}$, describe and interpret sex- and hormone-based studies of $\mathrm{AD}$, and discuss the importance of simulating human reproductive aging when modeling diseases of aging. With the human condition in mind, we then review mouse models of $\mathrm{AD}$, analyze reports of sex differences and hormone effects in male and female mice that model AD, raise major unresolved questions, and offer a research 
framework that incorporates human reproductive aging for future studies aimed at translational discoveries in the important area of sex and hormone biology.

\section{Alzheimer's disease AD}

Alzheimer's disease, the most common neurodegenerative condition, is reaching epidemic proportions. In the absence of effective interventions, over 50 million people worldwide will suffer from this devastating dementia by the year 2050 [2]. The symptoms of AD begin insidiously with memory impairment and then gradually progress to erode multiple cognitive and behavioral functions. The immeasurable burdens of the disease, combined with a history of failed clinical trials (reviewed in $[3,4]$ ) warrant urgent action toward the development of novel therapeutic targets based on a deeper understanding of AD.

\section{Cognitive decline in $A D$}

Progress in multiple fields of human and mouse model research has advanced our knowledge of what leads to cognitive decline in $\mathrm{AD}$ (for full review [5]). We now know that synaptic loss [6-8] and network dysfunction $[9,10]$ correlate more closely with cognitive deficits in $\mathrm{AD}$ than neuronal loss and degeneration. Furthermore, we have a growing appreciation based on imaging findings [11-13] and pathology studies [14-17] that the burden, distribution, or presence of amyloid plaques, pathologic hallmarks of $\mathrm{AD}$, do not correlate well with cognitive dysfunction. These human observations, combined with evidence from transgenic mouse models of $\mathrm{AD}$, also support the concept that plaques and neurofibrillary tangles, though potentially toxic in their own right [18-20], may not be the primary or driving cause of cognitive dysfunction. Highlights from this large body of literature include: cognitive deficits often develop prior to the deposition of amyloid plaques [21-23], neurofibrillary tangles can exist without neuronal impairment [14,16,2427], and tau alone can exert toxicity independently of neurofibrillary tangles (reviewed in [28]). Thus, a growing body of literature suggests that synaptic loss and dysfunction and network disruptions, rather than conventional pathological hallmarks, are main players in the development of cognitive decline in $\mathrm{AD}$.

\section{Multifactorial etiologies of $A D$}

$\mathrm{AD}$ is a complex disease caused by the interaction of many factors. Aging, itself, is the primary risk factor for the development of $\mathrm{AD}$ and aging-related problems such as diabetes, hypertension, and hyperlipidemia may further promote $\mathrm{AD}$ risk [29]. Genetic contributions to $\mathrm{AD}$ include mutations or alleles that increase risk such as ApoE4 [30-33] and GWAS-identified genes [30,34] or decrease risk such as the A673T coding variant in APP [35]. It is worth noting that, to date, all familial AD cases have been caused by either mutations, duplications, or overexpression, of the human amyloid precursor protein (hAPP) or by mutations in presenelin 1 (PS1) or presenelin 2 (PS2), which alter the processing of hAPP (reviewed in [36]).

The human genetics of AD, combined with several lines of evidence in human and mouse studies demonstrate a pathogenic role for $A \beta$, and particularly for soluble, oligomeric assemblies of $A \beta$ in synaptic and network dysfunction [10]. $A \beta$ can alter and depress synaptic function through mechanisms that involve NMDAR trafficking [37], tau mislocalization into dendritic spines [38,39], and a host of other mechanisms (reviewed in $[10,40]$ ) that may ultimately lead to network destabilization and cognitive dysfunction (reviewed in $[9,10,40]$ ).

\section{AD: $\operatorname{sex}^{\mathrm{a}}$ and epidemiology Epidemiology ${ }^{b}$}

Alzheimer's disease and mild cognitive impairment (MCI), a clinical state preceeding $\mathrm{AD}$, affect men and women in different ways. A thorough understanding of the sex-based differences in prevalence, incidence, and disease course can provide critical insight into potential targets for prevention. Of note, our review focuses on large-scale epidemiologic studies, which do not often specify effects of sex-influenced risk factors such as ApoE4, an important modifier of AD [5].

Here, we review epidemiologic data on AD with an emphasis on an important yet underappreciated sexual dimorphism: women bear a greater burden of $\mathrm{AD}$ due to increased prevalence and possibly incidence, but men suffer an aggressive course of the disease (Figure 1) [41-45]. In fact, one of the strongest predictors for an aggressive disease course and progression to death following a diagnosis of $\mathrm{AD}$ is male sex [44].

\section{Prevalence}

The prevalence of $\mathrm{AD}$, or the total number of cases in a population at a given time, is higher in women compared to men in multiple populations [46]. This is due, in large part, to female longevity - that is, women are more likely to live to ages when $\mathrm{AD}$ is most prevalent. In contrast to $\mathrm{AD}$, the prevalence of mild cognitive impairment (MCI), a cognitive state that precedes dementia, is higher in men in many populations [47-49], although not all studies are in agreement $[50,51]$. Together, these data suggest that men may be more vulnerable to the onset of the disease.

\section{Incidence}

The incidence of $\mathrm{AD}$, a measure of the risk of developing disease over time, is on the whole similar between men and women. Many epidemiologic studies show increased risk for the development of $\mathrm{AD}$ in women compared to men in specific populations, and many do 


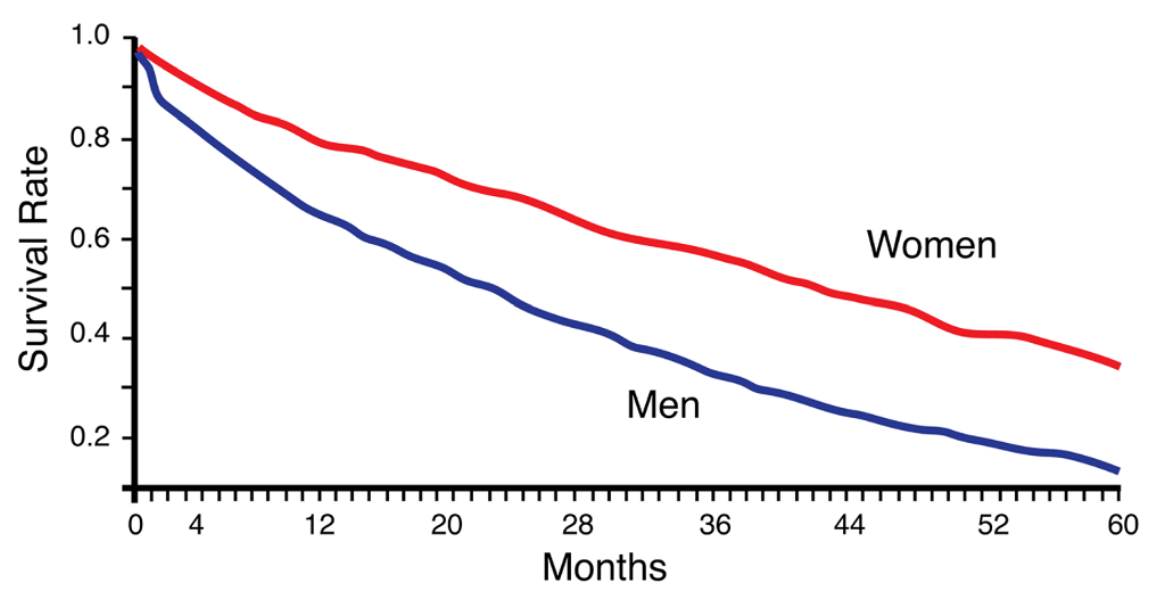

Figure 1 Males with AD progress to death faster than females. Survival rate in an AD cohort of age-matched men and women shows that males progress faster to death with sporadic AD in a manner that correlates most closely with cognitive decline. This effect is observed in sporadic [44,45] and early-onset AD [41-43]. Figure adapted from [45] with permission from Neurology.

not. A meta-analysis of studies worldwide shows similar risks between men and women that increase dramatically with age, and may increase disproportionately in women after the age of 80 yrs [52]. In parallel with increased prevalence of MCI in men, the Mayo Clinic Study of Aging also shows increased risk of MCI (or incidence rates) in men [53]. It will be important to see if other studies show the same.

\section{Disease Course}

Sexual dimorphism in the progression of AD is a major and meaningful epidemiologic measure that has received very little attention compared to incidence and prevalence. Men are more vulnerable to an aggressive disease course compared to women. This underappreciated sex difference is supported by several studies. First, men progress to death faster than women in both early- [41-43] and lateonset [44,45] AD (Figure 1). Since the sex difference exists in the presence and absence of other age-related comorbidities like cancer and heart failure, it suggests increased vulnerability to the pathophysiology of $\mathrm{AD}$ in men compared to women. In addition, the observed progression to death closely correlates with the rate of cognitive decline [54]. In further support of a more aggressive course of $A D$ in men, more studies are finding increased $\mathrm{MCI}$ in men $[47-49,53,55]$, suggesting increased vulnerability to the development and manifestation of cognitive deficits.

\section{AD: Disease course and mouse models}

Disease course may be the human epidemiologic factor most relevant to our study of AD in animal models. Since most mouse models of $\mathrm{AD}$ involve the transgenic expression of mutated APP with or without mutated tau, outcome measures are focused squarely on the manifestation or disease course rather than the risk or prevalence of disease.
Specifically, mouse models enable study of how a manipulation changes the manifestation or severity of AD-related disease measures such as pathology, biochemistry, cognition/behavior, synaptic/network plasticity, or survival.

\section{Human reproductive aging, hormone replacement and AD}

\section{Reproductive Aging}

Reproductive aging is a fundamental aspect of the aging process and is accompanied by dramatic decreases in certain gonadal steroid levels in human [56-60], but not rodent [61-64] males and females (Figure 2). Since AD is

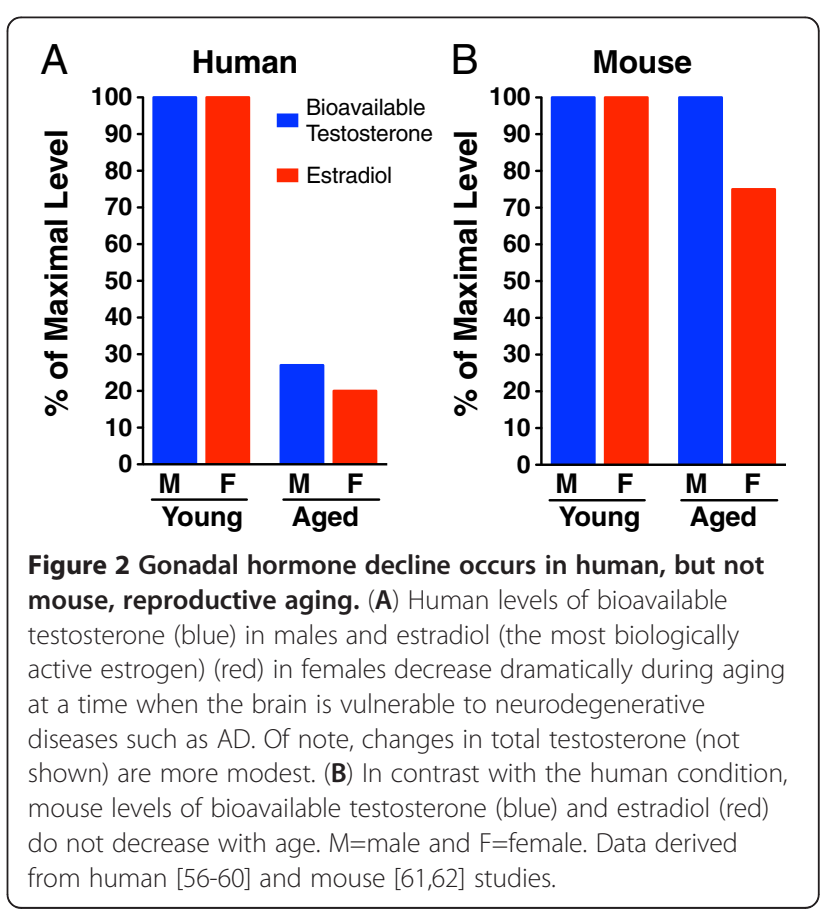


a disease of the aging brain and develops in a sex hormone-depleted environment, it is critical to study how gonadal steroid changes in menopause and andropause affect the risk and course of AD in women and men. Further, simulation of reproductive aging in mouse models of AD via gonadal steroid depletion represents a meaningful way to model the human condition.

\section{Women, AD, and Hormone Replacement Therapy (HRT)}

The results of randomized, controlled clinical trials, including the Women's Health Initiative (WHI) [65,66], found that HRT in women led to adverse [65-67] or no effects [68-70] on cognition or AD risk. These studies represent rigorous clinical trials; however, certain caveats such as hormone formulation, timing of therapy, and dose or route of hormone administration should be considered when interpreting the data (as reviewed in [71,72]). Ongoing [73] and future clinical studies should dissect whether HRT may be beneficial if given 1) during a "critical window"d after menopause, 2) by subcutaneous routes which largely bypass the liver, 3 ) in lower doses, 4) or in other formulations since conjugated equine estrogens without medroxyprogesterone acetate (Premarin) or with it (Prempro) may have differing biological activities from hormones typically used in animal studies (estradiol and progesterone). While future studies may shed light on these complex possibilities, the clinical data to date show that HRT, in its current forms, can be deleterious to cognitive outcomes.

Because $\mathrm{AD}$ pathophysiology begins and progresses years before its clinical manifestation [74,75], it is conceivable that HRT accelerated an existing disease process in women who experienced cognitive decline in clinical trials. Along the same lines, it is also possible that HRT benefits mood and cognition in the context of normal aging, but not in women already at risk for developing $\mathrm{AD}$. As we move closer to personalized medicine, the use of genetic, protein, and imaging biomarkers to predict healthy brain aging versus increased risk for $\mathrm{AD}$ and other diseases should serve as a clinical guide to whether HRT is appropriate for an individual woman.

\section{Men, AD, and Androgen Replacement}

Andropause is the male correlate of the female menopause, characterized by a gradual but steady decline of certain circulating gonadal steroids. A modest decrease in total testosterone accompanied by an increase in steroid hormone binding globulin (SHBG) results in a major decrease of bioavailable testosterone, averaging $1-2 \%$ per year beginning in the third or fourth decade of life [58,60,76-79]. Bioavailable testosterone (testosterone not bound to SHBG) has long been recognized as the biologically active, and thus most critical form of androgen.
Low levels of biologically active testosterone in the aging male may be deleterious to the brain. Despite new findings that SHBG might facilitate steroid delivery to target tissues (reviewed in $[80,81]$ ), both increased SHBG [82-84] and low levels of androgens (reviewed in [85]) are associated with increased dementia and AD risk. These observations, combined with studies of androgen treatment in humans and mice, suggest a protective role for androgens in cognition and AD (reviewed in [85]). Rigorous clinical trials to determine whether androgen replacement is indeed beneficial to cognition and dementia risk are needed.

\section{Simulating human reproductive aging in mouse models of $A D$}

An understanding of human AD epidemiology and reproductive aging, combined with intelligent research strategies to study effects of sex and hormones, set the stage to simulate the human condition using mouse models of AD. Both mice and humans undergo reproductive aging and subsequent decline in fertility. However two main differences in reproductive aging exists between the species. First, gonadal steroid levels decline in males and females during human aging [56-60] but not mouse aging [61-64] (Figure 2). Second, the primary cause of reproductive senescence in women is declining oocyte number and ovarian function [86]; in female rodents it is dysregulation of the neuroendocrine system $[87,88]$. Despite these differences, the unifying similarity in reproductive aging processes is that changes at all levels of the hypothalamic-pituitary-gonadal axis are important in both humans and rodents $[62,87,89]$.

Simulation of a prominent aspect of human reproductive aging in mice can be accomplished by gonadal steroid depletion through gonadectomy or other methods [90]. Since AD develops in the aging human brain, which is subject to effects of sex hormone depletion in both sexes, gonadectomy in mouse models of AD recapitulates a critical aspect of human reproductive aging in males and females.

\section{Strategies for studying hormone and sex effects in mouse models of $A D$ \\ Addressing human-relevant questions}

Since aging is the primary risk factor for AD and development of $\mathrm{AD}$ is restricted to the aging brain, the study of sex and hormones in light of reproductive aging, steroid depletion, and hormone replacement represents a translational framework for human-relevant research in mice. With this framework in mind, we propose three research areas, offer optimal research approaches using mice, and consider caveats. Each human-relevant question posed is followed by an optimal research approach using mice. 
1. Gonadal hormone depletion. The following questions focus on sex differences (Figure 3). a. Do males and females differ in AD-related outcome measures? Compare gonadectomized male and female mice to investigate sex differences.

b. If males and females differ in the absence of gonadal steroids, is the sex difference due to sex chromosomes or organizational effects of gonadal hormones? Delineate these possibilities using a genetic approach such as the "four core genotypes" (FCG) model (reviewed in [91,92]).

2. Reproductive aging. The following questions focus on effects of reproductive aging.

a. How does reproductive aging alter vulnerability to $\mathrm{AD}$ in females (Figure 4)? Compare "intact" to gonadectomized females. Stage of estrous cycle may also be taken into account since estrogen and progesterone, which can have opposing actions, fluctuate.

b. How does reproductive aging alter vulnerability to $\mathrm{AD}$ in males (Figure 5)? Compare "intact" (gonads present) to hormone-depleted (gonadectomized) male mice.

3. Hormone replacement. The following questions focus on effects of HRT.

a. How does hormone replacement in gonadal steroid-depleted females alter vulnerability to AD? Compare vehicle vs hormone treatment in hormone-depleted (gonadectomized) female mice (Figure 4). HRT doses, formulations, regimens,

\section{Sex Differences in mouse models of AD: Human-relevant research strategies}

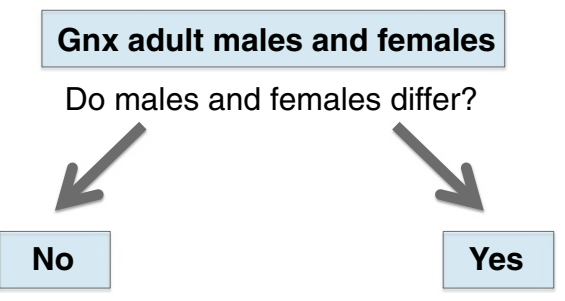

If sex difference was present in gonadally intact males vs females,

Consider effects of sex chromosomes or organizational it was hormonally modulated

Figure 3 Research strategy for studying sex differences in mouse models of AD. Gonadectomy of both male and female mice simulates gonadal steroid depletion that occurs in human reproductive aging. It also enables a direct comparison between the sexes that is less confounded by differential, activational effects of gonadal hormones in the male versus female brain.

\section{Studying females in mouse models of AD: Human-relevant strategies}

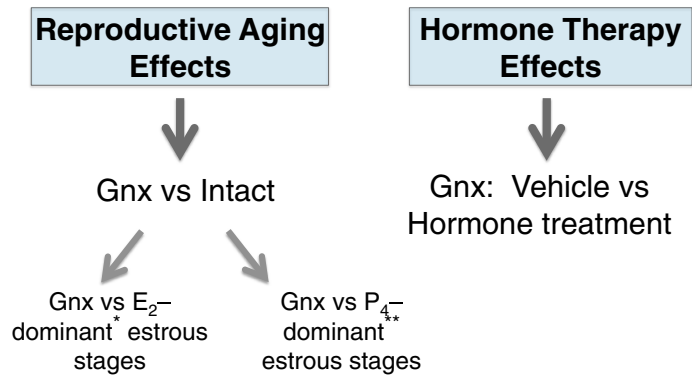

Figure 4 Research strategy for studying females in mouse models of AD. To determine how reproductive aging alters ADrelated measures in females, an appropriate strategy is comparing gonadectomized to intact mice. Intact females can be separated into estrogen dominant ${ }^{*}$ ( $E_{2}$ : proestrous, estrous) or progesterone dominant** $\left(\mathrm{P}_{4}\right.$ : metestrous, diestrous) stages of the reproductive cycle since these hormones can have opposing effects in the brain. To determine whether hormone replacement alters AD-related measures in females, an appropriate strategy is comparing vehicleversus hormone-treated mice that have all undergone gonadectomy to simulate human reproductive aging. $E_{2}$ is estradiol, the most biologically active estrogen in the mammalian reproductive cycle.

timing, and routes of administration can be tested, as guided by clinical questions.

b. How does hormone replacement in gonadal steroid-depleted males alter vulnerability to AD? Compare vehicle vs hormone treatment in hormone-depleted (gonadectomized) male mice (Figure 5).

Gonadectomy: considerations, caveats, and alternatives All three areas of research outlined above incorporate the strategy of depleting gonadal hormones though gonadectomy to mimic an aspect of human reproductive aging. This manipulation successfully depletes levels of gonadal hormones, but a few points regarding its limitations and optimal applications deserve consideration. First, gonadectomy decreases hormone levels in a subacute, rather than a slow and progressive manner, as occurs in human reproductive aging. However, whether the rate of hormone decline influences AD-related outcomes is unknown. Second, gonadectomy performed during middle-age (10-15 months in mice) may more closely model reproductive aging, since central nervous system changes that underlie reproductive aging have already occurred; but restricting studies to aging mice is not always practical or economically feasible. Finally, gonadal hormone depletion through natural or surgical means in humans [56,93-96] or gonadectomy in mice $[97,98]$ results in compensatory neuroendocrine responses 


\section{Studying males in mouse models of AD: Human-relevant strategies}

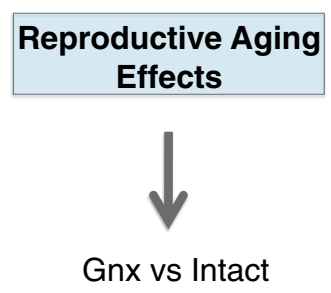

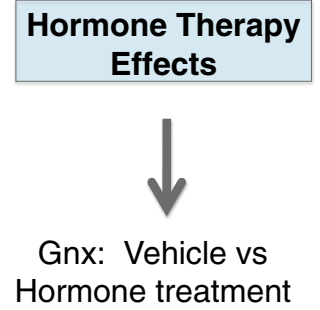

Figure 5 Research strategy for studying males in mouse models of AD. To determine how reproductive aging alters AD-related measures in males, an appropriate strategy is comparing gonadectomized to intact mice. To determine whether hormone replacement alters AD-related measures in males, an appropriate strategy is comparing vehicle- versus hormone-treated mice that have all undergone gonadectomy to simulate human reproductive aging.

such as increased luteinizing hormone (LH) and follicle stimulating hormone (FSH). Therefore, potential effects of $\mathrm{LH}$ and FSH cannot be ruled out when interpreting effects of gonadal hormone depletion. Nonetheless, since these compensatory changes occur in both simulated and true reproductive aging, the manipulation of gonadectomy in mouse models remains relevant to the human condition.

Alternatives to gonadectomy in female mice include genetic and chemical models of reproductive aging. The follitropin receptor knockout (FORKO) mouse is a genetic model that leads to chronic estrogen deficiency early in development $[99,100]$. An advantage of genetic models such as FORKO is the ability to recapitulate specific physiological mechanisms involved in human reproductive aging; however, limitations such as potential effects of the mutation on brain development and function could introduce confounds or constrain study interpretations. A chemical model of reproductive aging is treatment with 4-vinylcyclohexene diepoxide (VCD), an industrial chemical that induces follicle depletion and ovarian atrophy [90]. Benefits of VCD treatment include a more physiological, gradual decrease in gonadal steroid levels and the continued presence of the ovarian tissue [90]. Limitations of VCD are the absence of a comparable model in males (thus prohibiting studies on sex differences) and potential toxic effects on brain function that may be independent of gonadal steroid depletion.

Given current limitations of genetic and toxin models of reproductive aging in studying sex differences in mouse models of $\mathrm{AD}$, we advocate gonadectomy as a relevant and reliable manipulation.

Gonadal hormone depletion: dissecting a sex difference If the comparison between gonadectomized males and females reveals a sex difference, further mechanistic dissection can be achieved by determining whether sex chromosomes or organizational effects of hormones (longlasting effects of hormones that persist in their absence) explain the difference (Figure 3). One strategy to delineate these possibilities is through a genetic approach using the "four core genotypes" (FCG) model. FCG mice produce $\mathrm{XX}$ mice with ovaries, $\mathrm{XX}$ mice with testes, $\mathrm{XY}$ mice with ovaries, and XY mice with testes (reviewed in [91,92]). These mice can be crossed with transgenic mouse models of disease, including AD models. Gonadectomy of all male and female offspring in adulthood enables a complex but precise comparison of whether the observed sex difference is explained by sex chromosomes or organizational effects of gonadal hormones (as reviewed in [91]).

\section{Mouse models of AD}

Introduction. Using animal models

The necessity of dissecting molecular mechanisms and identifying potential therapies to improve the human condition requires using animal models of disease. A model is only useful, however, if the discoveries generated truly inform us about human disease and potential treatments. Thus, attention to aspects of the $\mathrm{AD}$ mouse model that recapitulate clinical manifestations of human $\mathrm{AD}$, such as cognition and its underlying substrates, is essential.

\section{AD mouse models}

While AD is a strictly human disease [101], the generation of genetically modified mice expressing mutations in genes that cause AD has enabled progress in understanding its pathogenesis. Genetic AD results from mutations in genes that regulate the production of $A \beta$ : APP, presenilin 1 (PS1), and presenilin 2 (PS2) (reviewed in [5,101-103]). Most AD mouse models overexpress a mutated form of the human APP gene, a combination of mutated APP and PS1, or a combination of APP, PS1 and P301L (a tau mutation causing frontotemporal dementia) (reviewed in $[101,102])$. Precise contributors to neural dysfunction, however, are not always clear in the models. For example, in transgenic hAPP mouse models, relative pathogenic contributions of different hAPP processing products are unknown. In addition, proteins such as endogenous APP have normal functions in synaptic physiology and neuronal migration (reviewed in $[104,105])$ that may be disrupted, further contributing to neural dysfunction.

The development of new mouse models of AD offers the opportunity to optimize paradigms and tackle 
unanswered questions. For example, models that express hAPP via targeted insertion and from the gene's own promoter might produce more physiological results. Yet, such "knock-in" models of AD have shown very mild, if any, tractable AD-like disease progression or dysfunction [106-108] to date. Other approaches in current development include modeling sporadic $\mathrm{AD}$, incorporating multifactorial etiologies of AD into models, and integrating other diseases of aging into AD models.

Despite the fact that current mouse models of AD are imperfect representations of the human condition, key features of AD are indeed preserved [101,102] and thus enable meaningful studies using these models. Most notably, transgenic mice show synaptic dysfunction/loss and network disruption, which correlate more closely with cognitive decline, the primary clinical manifestation of $\mathrm{AD}$, compared to other disease measures $[6,9]$.

\section{Relevant substrates of cognitive decline}

The efficacies of therapies, and their relevance to patients and families, depend on whether they can prevent or reverse cognitive decline, the primary clinical manifestation of $\mathrm{AD}$. Thus, its human relevance, combined with the incredible homology between rodent and human memory systems [109], make cognition and its substrates high-yield outcome measures in mouse models of AD. Since the main drivers for cognitive decline are synaptic loss/dysfunction and network disruptions, as discussed above (reviewed in $[6,10,40])$, these measures, along with their causative agents, are the most directly human-relevant assessments $[5,6]$.

\section{Review of studies on sex differences in mouse models of AD \\ Overview}

Sex-based differences in AD exist and comparisons between males and females that model $\mathrm{AD}$ are invaluable. Understanding sexual dimorphisms can inform us about what protects one sex or makes the other more vulnerable. Yet, studies that have compared AD-related measures in male versus female mice have reported quite varying results (cognitive differences reviewed in Table 1) making overall conclusions challenging at this time. We

Table 1 Sex Differences in cognition and behavior in mouse models of AD

\begin{tabular}{|c|c|c|c|c|}
\hline & $\begin{array}{l}\text { Hormone } \\
\text { Status, Age }\end{array}$ & Comparison & Cognition \& Behavioral Measure and Ref. & $\begin{array}{l}\text { AD Tg } \\
\text { Model }\end{array}$ \\
\hline \multirow[t]{14}{*}{ Baseline } & $\begin{array}{l}\text { Intact, } 8 \operatorname{mos}(F) \\
12 \operatorname{mos}(M)\end{array}$ & Intact: F vs M & F Tg $\uparrow$ activity vs F Ntg; M Tg no deficit (OF) [114] & APPswe-PS1dE9 \\
\hline & \multirow{2}{*}{$\begin{array}{l}\text { Intact, } 2-15 \text { mos [115], } \\
\text { 6-10 mos [121] }\end{array}$} & \multirow{2}{*}{ Intact: F vs M } & F Tg $\downarrow$ spatial/fear memory at some ages vs F Ntg \& M Tg (MWM, PA) [115] & $3 \times T g-A D[115]$ \\
\hline & & & F Tg↔M Tg impairment in novel object recognition (NOR) $[115,121]$ & TASTPM [121] \\
\hline & Intact, 2-14 mos & Intact: F vs M & F Tg $\downarrow$ SAB at 12-14 mos vs F Ntg and M Tg (Y-maze) [116] & $3 \times \operatorname{Tg}-\mathrm{AD}$ \\
\hline & \multirow[t]{2}{*}{ Intact, 2-17 mos } & \multirow[t]{2}{*}{ Intact: F vs M } & F Tg impaired and no change with age (CTA) [127] & \multirow[t]{2}{*}{ APPswe/ PS1dE9 } \\
\hline & & & M Tg increasingly impaired with age (CTA) [127] & \\
\hline & Intact, 6 mos & Intact: F vs M & $\begin{array}{c}\text { F Tg } \downarrow \text { activity/spatial memory/novel arm preference vs F Ntg; } \\
\text { M Tg no deficit (OF, MWM, Y-maze) [117] }\end{array}$ & $3 \times \operatorname{Tg}-\mathrm{AD}$ \\
\hline & Intact, 6 mos & Intact: F vs M & F Tg $\uparrow$ activity \& $\uparrow$ entries into light vs F Ntg; M Tg vice versa (OF, DLB) [118] & $3 \times \operatorname{Tg}-\mathrm{AD}$ \\
\hline & \multirow[t]{2}{*}{ Intact, 3, 9 mos } & \multirow[t]{2}{*}{ Intact: F vs M } & 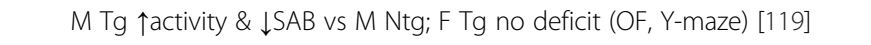 & \multirow[t]{2}{*}{ APPsW } \\
\hline & & & $\begin{array}{c}\text { F Tg } \downarrow \text { spatial memory vs F Ntg } 3 \text { mos; M Tg no } \\
\text { deficit (Circular Platform) }{ }^{\mathbf{A} ;}[119]\end{array}$ & \\
\hline & Intact,16 mos & Intact: F vs M & F Tg↔M Tg impairment in spatial acquisition memory (Barnes Maze) [122] & APPswe/ PS1dE9 \\
\hline & \multirow{2}{*}{$\begin{array}{l}\text { Intact, } 3,9 \text { mos [119], } \\
\quad 6 \text { mos [118] }\end{array}$} & \multirow[t]{2}{*}{ Intact: F vs M } & \multirow[t]{2}{*}{$\mathrm{F} \leftrightarrow \mathrm{M}, \mathrm{Tg} \leftrightarrow \mathrm{Ntg}$, no spatial learning impairments (MWM) $[118,119]$} & APPsw [119] \\
\hline & & & & $3 \times T g-A D[118]$ \\
\hline & Intact, 6, 15 mos & Intact: F vs M & M Tg $\uparrow$ center time vs F Tg and M Ntg (OF) [120] & $3 \times \operatorname{Tg}-\mathrm{AD}$ \\
\hline \multirow{4}{*}{$\begin{array}{l}\text { Response to } \\
\text { Manipulation }\end{array}$} & \multirow{2}{*}{$\begin{array}{l}\text { Intact, } 8 \operatorname{mos}(F) \\
12 \operatorname{mos}(M)\end{array}$} & \multirow[t]{2}{*}{ Intact: F vs M } & COX-2 overexp $\downarrow$ SAB in F Tg; no change or impairment in M Tg (Y-maze) [114] & \multirow[t]{2}{*}{ APPswe/ PS1dE9 } \\
\hline & & & COX-2 overexp $\leftrightarrow$ novel arm preference ${ }^{\mathbf{B}}$ in F or M, Tg or Ntg (Y-maze) [114] & \\
\hline & Intact, 6 mos & Intact: F vs M & Running $\uparrow o p e n$ arm entries in F Tg \& Ntg and $\downarrow$ in $M$ Tg \& Ntg $\left(E^{2} M^{\mathrm{C}}\right)$ [117] & $3 \times \operatorname{Tg}-\mathrm{AD}$ \\
\hline & Intact, 6 mos & Intact: F vs M & $\begin{array}{l}\text { Running } \uparrow \text { spatial memory/novel arm preference in F Tg vs } \\
\text { non-running F Tg; no effect or impairment in M Tg (MWM, Y-maze) [117] }\end{array}$ & $3 \times \operatorname{Tg}-\mathrm{AD}$ \\
\hline
\end{tabular}

Symbols: $\uparrow=$ increase, $\downarrow=$ decrease, $\leftrightarrow=$ no change or difference.

Abbreviations: $F=$ Female, $M=$ Male, Ntg=non-transgenic, $T g=$ transgenic, mos=months, $\mathrm{d}=$ day, $S A B=$ spontaneous alternating behavior (thought to reflect working memory), $M W M=$ Morris water maze, $O F=$ open field, $P A=$ passive avoidance, $C T A=$ conditioned taste aversion, $N O R=$ novel object recognition, $D L B=$ dark-light box, $E P M=$ elevated plus maze, $C O X-2=$ cyclooxygenase 2 , overexp=overexpression.

A, Latency to reach escape hole and number of errors.

B, Preference for the novel arm in Y-maze thought to reflect spatial recognition memory [114].

C, No 3xTg-AD effect was observed in the EPM [117]. 
believe that the variation in data is probably not random and, in large part, results from the inherently complex comparison of gonadally intact males with gonadally intact, cycling females - a comparison involving multiple layers of biologic effects. Consider the following:

1. If a sex difference exists (or not), it may result from differential activational effects of endogenous gonadal steroids in the male versus the female brain. That is, actions of androgen in the male brain may differ from actions of estrogens or progesterone in the female brain. It is also possible that the sex difference may exist even in the absence of gonadal hormones.

2. Androgen levels remain constant in males while estrogen and progesterone levels fluctuate in females across the estrous cycle. Stages of the estrous cycle influence brain functions of females in diametrically opposing ways [110]. Since female mice cycle synchronously, AD-related outcome measures in females may be biased toward either an estrogendominant (proestrous or estrous) [111-113] or a progesterone-dominant (metestrous or diestrous) [111-113] state. Conversely, important hormonemediated effects in females could be missed if multiple estrous stages are inevitably combined in the experimental group.

3. The ability to detect, repeat, or precisely interpret a sex difference in mouse models of $\mathrm{AD}$ can be obscured by points one and two.

In light of these complexities, we review the current literature on sex differences in mouse models of AD and stress that while comparing gonadally intact males and females is a valuable first step, studies that incorporate human-relevant manipulations to model reproductive aging via gonadal steroid depletion in both sexes are urgently needed.

\section{Cognition and Behavior}

For the reasons outlined above, it may not be surprising that reports on sex differences between intact male mice compared to intact female mice in AD-relevant cognitive and behavioral tasks vary considerably, even within the same AD model (Table 1). At baseline, females were more impaired than males [114-119], males were more impaired than females $[119,120]$, and the two sexes did not differ $[115,118,119,121,122]$. There was similar variation in sex differences resulting from genetic or other manipulations in mice that model AD (Table 1). That is: females worsened [114,117], improved [117], or did not differ [114] compared to males. We emphasize that this variability is probably not random, but results from the complexities of differential hormonal actions in male and female brains.
It is curious, however, that intact females are impaired slightly more often than intact males when considering all studies together. While these studies have concluded that female mice are more vulnerable to AD-related deficits, we offer two additional interpretations: in mouse models of $\mathrm{AD}, 1)$ female gonadal hormones are more deleterious in female brains than male hormones in male brains or 2) male gonadal hormones are more beneficial in male brains than female hormones in female brains. It will be necessary to further dissect these complex possibilities, beginning by simply depleting gonadal steroids and then comparing males to females. Gonadal steroid depletion in male and female mice will enable us to determine what sex differences exists in a hormonal milieu that is more comparable to the human condition (Figure 3).

\section{$A \beta$, tau, and histopathology}

Like cognitive and behavioral data on intact males and females that model $A D$, there is considerable variation in reports of sex differences in baseline $A \beta$ levels and amyloid plaque deposition: females had higher levels than males [116-118,121,123-132], males had higher levels than females $[133,134]$, and the two sexes did not differ $[115,135,136]$. In addition, tau levels did not differ in intact males and females $[115,123]$. Similar variation in sex differences of $A \beta$ levels, amyloid plaque deposition, and tau is observed in response to stress, pharmacologic, and genetic manipulations of mouse models of AD [114,128,131-134,136-139].

As we learn more about the pathophysiology underlying $\mathrm{AD}$, we are coming to appreciate that moderate differences between plaque load or neurofibrillary tangle abundance bear less biologic relevance to cognition than once thought. Nonetheless, levels of plaques and tangles, combined with more toxic assemblies of $A \beta$ and tau should be further assessed in gonadal steroid depleted mice.

\section{Molecular and Biochemistry}

Many studies have examined molecular and biochemical differences between gonadally intact male and female mice that model AD. Among reports are measures of: hAPP processing enzymes and products [123,125,130,133,134,137], corticosteroids [115,120,135], metals [125,130,140,141], immune modulators [131], lipids and their peroxidation products [142], and other factors [128,129,132,143]. All of these measures undoubtedly bear relevance to $\mathrm{AD}$ and its pathophysiology. But the significance of the molecular and biochemical sex differences will become clearer with further mechanistic dissection. Do the sex differences persist following depletion of gonadal hormones? If so, how do the molecular and biochemical measures relate to cognitive and behavioral 
performance in AD models? Factors that correlate well with either protective or detrimental cognitive measures in the absence of gonadal steroids, might lead to important sex-based therapeutic targets in the treatment of AD.

\section{Survival}

Mice that model AD suffer premature mortality [119,120,144-150] in parallel with the human condition. However, whether the striking sexual dimorphism in survival - men with $\mathrm{AD}$ progress faster to death than women [41-45] - is recapitulated in mouse models, remains to be determined. Premature mortality has been reported in both sexes [119] but further investigation into this AD-relevant measure is currently lacking. Sex differences in survival bear relevance to the human condition, and may hold promise for revealing novel targets for the development of therapies, if mouse models parallel human epidemiologic findings.

\section{Conclusions and future directions}

While comparing intact male and female mice that model $\mathrm{AD}$ is an initial step, we propose that the next step requires modeling human reproductive aging (depleting gonadal steroids via gonadectomy) in mice. We strongly advocate for this research strategy with the following scientific rationales:

1. $\mathrm{AD}$ is a disease of aging that, in humans, develops in a gonadal steroid-depleted state; thus, depleting gonadal steroids in mice is a human-relevant manipulation.

2. Endogenous gonadal steroids profoundly impact cognition and brain function (reviewed in [151-156]); thus, removing gonadal steroids in males and females enables a more direct comparison between sexes that is less confounded by "activational" effects of endogenous gonadal steroids.

In the presence of endogenous gonadal steroids, differences between males and females may result from differential actions of androgens in males, or of estrogen/ progesterone in females. Further, hormonal effects in females will vary according to the stage in estrous cycle [111-113]. Thus, removing gonadal steroids enables a more precise comparison between the sexes.

\section{Review of studies in mouse models of AD: females Overview}

Whether and how reproductive aging or hormone replacement alters vulnerability to $\mathrm{AD}$ in females are outstanding questions. Some answers are taking form, but the overall picture remains unclear. Since the WHI and other clinical studies reported negative impacts of HRT on cognition and AD risk [65-67], some mouse studies have begun to determine whether timing, dose, regimen, or route of administration of hormone therapy alters its effects. Key issues in interpreting the results of the mouse studies, which are more fully described in Table 2, are reviewed. Of note, our review is focused on estradiol ${ }^{\mathrm{c}}$ (the most biologically active estrogen) and progesterone effects in female mice since these are the principle, systemic gonadal hormones decreased following menopause; but other steroids, including neurosteroids ([180] and reviewed in $[157,158]$ ), may also play a role in $\mathrm{AD}$.

\section{Cognition and behavior}

While estradiol facilitates synaptic plasticity and several forms of hippocampal-dependent learning and memory in the adult and aging rodent brain, (reviewed in [151-153]), its role in memory of the diseased brain remains less clear. To date, studies examining hippocampal-dependent spatial learning/memory in AD mouse models find no effects of gonadal hormone depletion $[159,160]$, or estradiol replacement $[159,160]$ in water maze tasks, despite estradiol-mediated decreases in $A \beta$ levels or deposition [161-168]. In parallel, progesterone replacement also failed to alter AD-related impairments in the watermaze [169].

In contrast to the watermaze studies, studies in the $3 \mathrm{xTg}$ mouse model show impaired working memory in the Y-maze following gonadectomy [162-163] - an effect that is reversed by estradiol [162-164] but not progesterone replacement [163-164]. The effect of estradiol is mimicked by an ER $\alpha$ but not ER $\beta$ agonist [162] and persisted with a combined estradiol and cyclical progesterone regimen [164]. More studies of females are needed in AD mouse models to draw conclusions and determine: whether certain AD models are more sensitive to hormonal effects compared to others (and why), if hormone replacement differentially affects certain cognitive domains and not others in the diseased brain, and ultimately whether hormonal effects on cognition and behavior in female $\mathrm{AD}$ model-mice reliably recapitulate human findings.

\section{$A \beta$, tau, and histopathology}

A large body of evidence, with notable exceptions $[136,159,160,170]$, supports a role for estradiol [161-168,171] and other hormone replacement regimens [164] in decreasing $A \beta$ levels and plaques. However, estrogenmediated decreases of $A \beta$, even in its more toxic forms, do not correlate consistently with improved cognition. This striking disconnect, combined with adverse cognitive effects of estrogen replacement in human AD trials $[65,66]$ lead us to speculate that estrogens may be detrimental to substrates of learning and memory in the diseased brain - and that this harmful action negates their 
Table 2 Female studies of cognition \& behavior in mouse models of AD

\begin{tabular}{|c|c|c|c|c|c|}
\hline $\begin{array}{l}\text { Hormone/ } \\
\text { Regimen }\end{array}$ & Manipulation & Timing, Route, Dose & Comparison $^{A}$ & $\begin{array}{l}\text { Cognition \& Behavioral } \\
\text { Measure and Ref. }\end{array}$ & AD Tg Model \\
\hline \multirow{4}{*}{$\begin{array}{l}\text { Hormone } \\
\text { Depletion }\end{array}$} & \multirow[t]{2}{*}{ Gnx 3 mos } & \multirow[t]{2}{*}{$\mathrm{N} / \mathrm{A}$} & \multirow[t]{2}{*}{ Intact vs Gnx } & Gnx $\downarrow$ SAB (Y-maze) [162'163] & \multirow[t]{2}{*}{$3 \times \operatorname{Tg}-A D$} \\
\hline & & & & Gnx $\downarrow$ open arm time (EPM) [164] & \\
\hline & Gnx 3 mos & N/A & Intact vs Gnx & Gnx ↔ spatial memory (MWM) [159] & APP+PS1 \\
\hline & VCD 2-2.5 mos & N/A & Intact vs VCD & $\begin{array}{c}\text { VCD } \leftrightarrow \text { spatial/working memory } \\
\text { (RAWM) [160] }\end{array}$ & APPswe \\
\hline \multirow[t]{6}{*}{ Estrogens } & \multirow[t]{2}{*}{ Gnx 3 mo } & \multirow[t]{2}{*}{ Immediate s.c. $E_{2}(0.025$ mg) $90 \mathrm{~d}$} & \multirow[t]{2}{*}{ Gnx: Veh vs $E_{2}$} & $\mathrm{E}_{2} \uparrow \mathrm{SAB}$ (Y-maze) [162-164] & \multirow[t]{2}{*}{$3 \times \operatorname{Tg}-A D$} \\
\hline & & & & $E_{2} \downarrow$ freezing (FST) $[164]$ & \\
\hline & Gnx 3 mos & Immediate s.c. PPT (0.25 mg) $90 \mathrm{~d}$ & Gnx: Veh vs PPT & $\mathrm{PPT} \uparrow \mathrm{SAB}$ (Y-maze) [162] & $3 x \operatorname{Tg}-\mathrm{AD}$ \\
\hline & Gnx 3 mos & Immediate s.c. DPN (0.25 mg) $90 \mathrm{~d}$ & Gnx: Veh vs DPN & DPN ↔ SAB (Y-maze) [162] & $3 x \operatorname{Tg}-A D$ \\
\hline & Gnx 3 mos & $\begin{array}{c}\text { Immediate, } 3, \& 6 \text { mo later, s.c. } E_{2} \\
\text { (0.18 mg) }\end{array}$ & $G n x$ vs $G n x+E_{2}$ & $E_{2} \leftrightarrow$ spatial memory (MWM) [159] & $\mathrm{APP}+\mathrm{PS} 1$ \\
\hline & VCD 2-2.5 mos & Immediate s.c. $E_{2}(0.36 \mathrm{mg}) 90 \mathrm{~d}$ & VCD vs VCD $+E_{2}$ & $\begin{array}{c}E_{2} \leftrightarrow \text { spatial/working memory } \\
\text { (RAWM) [160] }\end{array}$ & APPswe \\
\hline \multirow[t]{3}{*}{$\mathrm{P}_{4}$ Continuous } & \multirow[t]{2}{*}{ Gnx 3 mos } & \multirow[t]{2}{*}{ Immediate s.c. $P_{4}(25 \mathrm{mg}) 90 \mathrm{~d}$} & \multirow[t]{2}{*}{ Gnx: Veh vs $\mathrm{P}_{4}$} & $\mathrm{P}_{4} \leftrightarrow \mathrm{SAB}\left(\mathrm{Y}\right.$-maze) $\left[163^{\prime} 164\right]$ & \multirow[t]{2}{*}{$3 \times \operatorname{Tg}-A D$} \\
\hline & & & & $\begin{array}{c}P_{4} \uparrow \text { open arm time, } \downarrow \text { freezing } \\
\text { (EPM, FST) [164] }\end{array}$ & \\
\hline & Gnx 6 mos & Immediate s.c. $P_{4}(25 \mathrm{mg}) 90+d$ & $G n x$ vs $G n x+P_{4}$ & $\begin{array}{c}P_{4} \leftrightarrow \text { spatial memory (NPR, MWM) } \\
{[169]}\end{array}$ & $\begin{array}{l}\text { APPswe+ } \\
\text { PSEN1 } 1 \text { E9 }\end{array}$ \\
\hline \multirow[t]{2}{*}{$\mathrm{P}_{4}$ Cyclical } & \multirow[t]{2}{*}{ Gnx 3 mos } & \multirow{2}{*}{$\begin{array}{c}\text { Delayed s.c. } P_{4}(2.8 \mathrm{mg}) 10 \mathrm{~d} \\
\text { off/on }\end{array}$} & \multirow[t]{2}{*}{ Gnx: Veh vs $P_{4}$} & $P_{4} \leftrightarrow S A B(Y-m a z e)[164]$ & \multirow[t]{2}{*}{$3 \times \operatorname{Tg}-A D$} \\
\hline & & & & $\begin{array}{l}\mathrm{P}_{4} \uparrow \text { open arm time, } \downarrow \text { freezing } \\
(\mathrm{EPM}, \mathrm{FST})[164]\end{array}$ & \\
\hline \multirow[t]{3}{*}{$\begin{array}{l}E_{2}+P_{4} \\
\text { Continuous }\end{array}$} & Gnx 3 mos & $\begin{array}{l}\text { Immediate s.c. } E_{2}(0.025 \mathrm{mg})+\mathrm{P}_{4} \\
(25 \mathrm{mg}) 90 \mathrm{~d}\end{array}$ & Gnx: Veh vs $E_{2}+P_{4}$ & $\mathrm{E}_{2}+\mathrm{P}_{4} \uparrow \mathrm{SAB}(\mathrm{Y}$-maze) $[163]$ & $3 \times \operatorname{Tg}-A D$ \\
\hline & \multirow[t]{2}{*}{ Gnx 3 mos } & \multirow{2}{*}{$\begin{array}{l}\text { Immediate s.c. } E_{2}(0.025 \mathrm{mg})+P_{4} \\
(25 \mathrm{mg}) 90 \mathrm{~d}\end{array}$} & \multirow[t]{2}{*}{ Gnx: Veh vs $E_{2}+P_{4}$} & $\mathrm{E}_{2}+\mathrm{P}_{4} \leftrightarrow \mathrm{SAB}$ (Y-maze) [164] & \multirow[t]{2}{*}{$3 \times \operatorname{Tg}-A D$} \\
\hline & & & & $\begin{array}{c}E_{2}+P_{4} \uparrow \text { open arm time, } \downarrow \text { freezing } \\
\text { (FST, EPM) [164] }\end{array}$ & \\
\hline \multirow[t]{2}{*}{$E_{2}+P_{4}$ Cyclical } & \multirow[t]{2}{*}{ Gnx 3 mos } & \multirow{2}{*}{$\begin{array}{l}\text { Immediate s.c. } E_{2}(0.025 \mathrm{mg}) 90 \mathrm{~d} \\
\quad+\mathrm{P}_{4}(2.8 \mathrm{mg}) 30 \mathrm{~d} \text { cycles }\end{array}$} & \multirow[t]{2}{*}{ Gnx: Veh vs $E_{2}+P_{4}$} & $E_{2}+P_{4} \uparrow S A B(Y-m a z e)[164]$ & \multirow[t]{2}{*}{$3 \times \operatorname{Tg}-A D$} \\
\hline & & & & $\begin{array}{c}E_{2}+P_{4} \uparrow \text { open arm time, } \downarrow \text { freezing } \\
\text { (FST, EPM) [164] }\end{array}$ & \\
\hline LH Depletion & $21 \mathrm{mos}$ & $\begin{array}{l}\text { I.M. injection of leuprolide followed } \\
\text { by depot }(7.5 \mathrm{mg} / \mathrm{kg})\end{array}$ & $\begin{array}{l}\text { Intact: Veh vs } \\
\text { leuprolide }\end{array}$ & $\begin{array}{c}\text { leuprolide } \uparrow \text { SAB in aging (Y-maze) } \\
{[180]}\end{array}$ & $\operatorname{Tg} 2576$ \\
\hline Testosterone & Postnatal d1-7 & IP injection of $\mathrm{T}(100 \mu \mathrm{g} / \mathrm{d})$ & Intact: Veh vs T & $T \leftrightarrow S A B$ (Y-maze) [116] & $3 \times \operatorname{Tg}-A D$ \\
\hline
\end{tabular}

Symbols: $\uparrow=$ increase, $\downarrow=$ decrease, $\leftrightarrow=$ no change.

Abbreviations: $T g=$ transgenic, mos=months, $d=$ day, $E_{2}=$ estradiol (a type of estrogen), $P_{4}=$ progesterone, $L H=$ Leutinizing hormone, $V C D=4$-vinylcyclohexene diepoxide (causes chemically-induced ovarian atrophy), s.c.=subcutaneous, I.M.=intramuscular, IP=intraperitoneal, $S A B=$ spontaneous alternating behavior (thought to reflect working memory), $F S T=$ forced swim test, $R A W M=$ radial arm water maze, $N P R=$ novel place recognition, $E P M=e$ evated plus maze, $P P T=$ Propylpyrazole triol (ERa agonist), DPN= Diarylpropionitrile (ERß agonist), leuprolide=leuprolide acetate (gonadotropin-releasing hormone agonist).

A, All comparisons are between groups of AD Tg mice.

beneficial effects on lowering $A \beta$. Studies are needed to explore this untested hypothesis.

\section{Molecular and Biochemistry}

Consistent with estradiol-mediated decreases in $A \beta$ levels, estradiol treatment suppresses the $A \beta$ producing $\beta$-secretase 1 (BACE) [168], and increases the $A \beta$ catabolizing Insulin-degrading enzyme (IDE) [165]. Although this may explain decreased $A \beta$ levels, the conundrum of the hormone's effect on cognition in the diseased brain remains.

\section{Survival}

Studies have reported survival data in female AD-model mice following gonadal hormone depletion or hormone replacement - and consistently show that estrogens are toxic. Estradiol treatment increased mortality in both intact and hormone-depleted adult female APPswe mice [160]. Interestingly, removal of gonadal steroids before sexual maturity, via gonadectomy, increased mortality in this model [172]; however, when depletion of gonadal steroids was delayed until after sexual maturity, premature mortality did not occur [160]. Since premature mortality in mouse models of $\mathrm{AD}$ is closely associated 
with sudden death from seizures [144-150], the studies suggest that estrogens may increase network excitability leading to seizure-related death in adult, female ADmodel mice. In support of this, decreasing brain estrogens through anastrozole in the adult female brain increased survival in 3xTg-AD mice [136].

\section{Conclusions and future directions}

The known enhancing effects of estradiol on synaptic plasticity and memory in the normal brain (reviewed in [151153]), juxtaposed to its conflicting effects on cognition in the diseased brain, lead us to an intriguing hypothesis we wish to put forth: Estrogens benefit cognition in the normal, aging brain but not in the diseased, AD brain (or in the brain at risk for AD) (Figure 6). In support of this hypothesis, is data from human clinical trials $[65,66]$ and the following untested rationale. Estrogens increase excitability in the normal brain (reviewed in $[151,152]$ ), a process that facilitates normal learning and memory. However, this same action in the hyperexcitable AD-brain could lead to excitotoxicity and memory impairment. Answers to this untested hypothesis could dramatically impact the future of personalized HRT.

\section{Review of studies in mouse models of AD: males Overview}

Whether androgens, or other forms of hormone replacement in men with $\mathrm{AD}$ are beneficial has yet to be determined in rigorous, double-blinded, prospective, and placebo-controlled clinical trials - but clinical observations $[85,173-176]$ and data from animal studies suggest they may be. Studies of hormone depletion and

\section{Hypothesis for differential effects of estrogen in health and disease}

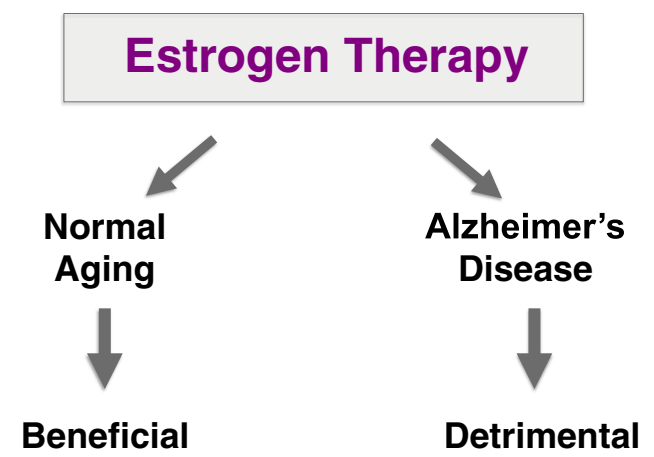

Figure 6 Hypothesis: Estrogen replacement therapy is beneficial in normal aging, but detrimental in $A D$ or to those at risk of developing $A D$. treatment in male mice that model AD collectively show a beneficial action of androgens on cognition, pathology, and biochemical measures.

\section{Cognition and behavior}

Gonadal steroid depletion, via gonadectomy of male mice that model AD, worsened cognitive impairment [177]. The impairment was reversed by subcutaneous treatment with dihyrdotestosterone (DHT) [177], a metabolite of testosterone. Increasing serum and brain levels of testosterone via genetic knockdown of aromatase [178] also improves cognition in male AD mice. The possibility that androgens may exert long lasting "organizational" effects is supported by a finding that blocking androgen receptors during a critical period of brain differentiation in male 3xTg mice worsens cognition in adulthood [116]. Collectively, these studies (Table 3) show a reproducible, beneficial effect of androgen-related function on cognitive impairments in male mice that model AD.

\section{$A \beta$, tau, and histopathology}

In parallel with protecting against cognitive deficits, androgens also decreased levels of pathogenic proteins and pathology related to AD. While gonadectomy increased $\mathrm{A} \beta$ levels and plaque deposition in male $\mathrm{AD}$ model mice $[177,179]$, elevating androgens through hormone replacement $[177,179]$ or genetic knockdown of aromatase [178] decreased these measures. In addition, transient androgen receptor blockade in the neonate [116] curiously increased $A \beta$ accumulation in adulthood, suggesting that androgens can exert organizational effects on propensity toward $A \beta$ pathology. Gonadectomy did not change levels of tau in male $3 x T g$ mice [179], but testosterone decreased tau levels compared to both gonadectomized and intact mice [179].

\section{Molecular and biochemistry}

Consistent with androgen-mediated decreases in $A \beta$ levels, elevating brain and serum testosterone via aromatase knockdown, modified important enzymes (BACE, neprilysin (NEP), and IDE) leading to decreased $A \beta$ production [178]. These data offer an explanation for androgen's protective actions in lowering levels of $A \beta$ and, ultimately, improving cognition. Although more studies have addressed molecular and biochemical measures in in vitro, cell culture systems, they are not reviewed here.

\section{Survival}

No studies to date have examined if androgens, or the lack of, alter survival in male mice that model AD.

\section{Conclusions and future directions}

Though the number of studies is limited, they collectively show a deleterious effect of gonadectomy and a 
Table 3 Male studies of cognition \& behavior in mouse models of AD

\begin{tabular}{|c|c|c|c|c|c|}
\hline Hormone/ Regimen & Manipulation & Timing, Route, Dose & Comparison $^{A}$ & $\begin{array}{l}\text { Cognition \& Behavioral } \\
\text { Measure and Ref. }\end{array}$ & $\begin{array}{l}\text { AD Tg } \\
\text { Model }\end{array}$ \\
\hline Hormone Depletion & Gnx 3 mos & $\mathrm{N} / \mathrm{A}$ & Intact vs Gnx & Gnx $\downarrow$ SAB (Y-maze) [177] & $3 \times \operatorname{Tg}-A D$ \\
\hline Flutamide $^{B}$ & Postnatal d1-20 & $\begin{array}{l}\text { IP injection of flutamide } \\
(50 \mathrm{mg} / \mathrm{kg} / \mathrm{d})\end{array}$ & Intact: Veh vs Flutamide & Flutamide $\downarrow$ SAB (Y-maze) [116] & $3 \times \operatorname{Tg}-A D$ \\
\hline $\begin{array}{l}\text { Genetic Knockdown } \\
\text { of Aromatase }\end{array}$ & None & N/A & $\begin{array}{l}\text { Intact: } \text { Aromatase }^{+/-} \text {vs } \\
\text { Aromatase }^{+/+}\end{array}$ & $\begin{array}{c}\text { Aromatase }{ }^{+/-} \uparrow \text { spatial memory } \\
\text { (Hole-board) [178] }\end{array}$ & APP23 \\
\hline DHT & Gnx 3 mos & $\begin{array}{c}\text { Immediate s.c. DHT } \\
\text { (10 mg) } 90+d\end{array}$ & Gnx: Veh vs DHT & DHT $\uparrow$ SAB (Y-maze) [177] & $3 \times \operatorname{Tg}-A D$ \\
\hline
\end{tabular}

Symbols: $\uparrow=$ increase, $\downarrow=$ decrease, $\leftrightarrow=$ no change.

Abbreviations: $T g=$ transgenic, $m o s=$ months, $d=$ day, $G n x=$ gonadectomy, $S A B=$ spontaneous alternating behavior (thought to reflect working memory), $I P=$ =intraperitoneal, Veh=Vehicle, $D H T=$ dihydrotestosterone.

A, All comparisons are between groups of AD Tg mice.

B, Flutamide is an androgen receptor antagonist.

C, Males with aromatase knockdown have increased endogenous testosterone levels, and decreased brain and sera estradiol levels.

protective action of androgens in male mice that model AD. The protective effect existed in more than one AD model, was achieved using genetic or pharmacologic strategies, and modified a directly relevant measure to clinical AD - cognition. Several important questions arise from these studies. How do androgens modulate $A \beta$-targeting enzymes and can they protect against cognitive deficits in an $\mathrm{A} \beta$-independent manner? Do androgens signal through receptor-dependent or alternate pathways to achieve protection? Can androgen signaling improve AD-related cognitive deficits in both males and females? If so, can we modify androgen signaling to improve cognition without eliciting masculinizing effects? These and other lines of androgen-focused investigation may hold promise for treating the human condition.

\section{Where do we go from here? Research strategies}

Given our evolving tools and knowledge base, we put forth the following suggestions for future research in sex- and hormone-based studies in AD mouse models. First, since gonadal steroid depletion is an inextricable aspect of human, but not mouse, aging, it should be vigorously incorporated into our study of $\mathrm{AD}$ and other disease models of aging. Gonadal steroid depletion through gonadectomy is a human-relevant manipulation that models the hormone environment in which $\mathrm{AD}$ develops and enables clearer approaches to comparing males and females, understanding reproductive aging, and testing effects of hormone replacement. Second, when using mouse models of $\mathrm{AD}$, measures that relate closely to clinical AD, and thus directly reflect humanrelevant outcomes, should be included in studies. This means expanding the focus of mouse model research to include cognition, behavior, and measures closely correlated with these, such as synaptic and network function. Third, because clear sex differences exist in human AD epidemiology, specifically in progression to death, it is important to look at survival and related measures in our mouse models. Finally, in light of past, present, and future clinical trials, we should continue lines of research studying how the loss and replacement of hormones affect each sex in models of AD.

\section{Outlook}

As we learn more about AD itself, how it manifests differently in men compared to women, and how hormones modify its risk, we must simultaneously recast our questions to reflect high-yield and human-relevant research strategies - with the goal of achieving biomedical discoveries that improve the human condition. This is not an easy task, as it requires merging the complex, emerging field of sex and hormone biology with the study of a complex, devastating disease of aging, AD. We believe this task is not insurmountable, and if taken on mindfully, may reveal novel targets for defeating the disease.

\section{Endnotes}

${ }^{\mathrm{a}} \mathrm{Sex}$ is biological classification of living beings as male or female and is used in this review to describe both humans and mice. Gender, a term that is only appropriate when applied to humans, is a cultural expression of sex, shaped by environment and experience.

${ }^{\mathbf{b}}$ This review of sex differences in the epidemiology of $\mathrm{AD}$ includes large populations in which the effect of ApoE4, a genetic risk factor that increases AD risk in women, is not specifically examined.

${ }^{\mathbf{c}}$ Estradiol is the most biologically active form of estrogen that circulates in high levels in the body prior to the menopause in women. Most studies in animal models use estradiol for hormone treatment. In contrast, clinical studies in humans have used hormone replacement paradigms that include other estrogenic steroids.

${ }^{\mathrm{d}}$ During the publication process of our review, an observational study showing an association between hormone therapy use started within 5 years of menopause and decreased AD risk was released $(\mathrm{H}$. Shao et al. Hormone 
therapy and Alzheimer disease dementia: New findings from the Cache County Study. Neurology 79, 1846). Though the findings are highly intriguing in light of the critical window hypothesis, caution must be exercised when interpreting observational studies due to their inherent limitations. Ultimately this study approach can only show associations and not causal links. Whether hormone therapy reduces the risk of $\mathrm{AD}$ when given during a critical window will need to be determined through the goldstandard of clinical research - randomized, double-blind, placebo-controlled trials.

\section{Competing interest}

The authors declares that they have no competing interest.

\section{Authors' contributions}

$\mathrm{DD}, \mathrm{LB}$ and $\mathrm{KW}$ reviewed the literature. DD and LB wrote the review. All authors read and approved the final manuscript.

\section{Authors' information}

Dena B Dubal, MD, PhD is an Assistant Professor of Neurology and Director of the Laboratory for Neuroscience and Aging Research. She holds the David Coulter Endowed Chair in Aging and Neurodegeneration at UCSF. She is a physician-scientist with a clinical and research focus on intersections between aging and neurodegeneration.

Lauren Broestl is a Research Associate in the department of Neurology at UCSF.

Kurtresha Worden is a Research Associate in the department of Neurology at UCSF.

\section{Acknowledgements}

This work was supported by National Institutes of Health Grant AG034531 (D.B.D.) and the Coulter-Weeks Foundation (D.B.D.). We thank P. Wise and J. Palop for discussions and L. Bonham, F. Lee, and A. Boltunova for discussions and administrative assistance.

Received: 9 August 2012 Accepted: 27 September 2012 Published: 5 November 2012

\section{References}

1. Pankevich DE, Wizemann TM, Altevogt BM, Institute of Medicine (U.S.): Forum on Neuroscience and Nervous System Disorders. In Sex differences and implications for translational neuroscience research: workshop summary. Washington, D.C: National Academies Press; 2011.

2. Wimo A, Prince M: World Alzheimer Report 2010: the global economic impact of dementia. In Book World Alzheimer Report 2010: the global economic impact of dementia: Alzheimer's Disease International (ADI); 2010:1-56.

3. Lindner MD, MCArthur RA, Deadwyler SA, Hampson RE, Tariot PN: Chapter 4: Development, Optimization and Use of Preclinical Behavioral Models to Maximize the Productivity of Drug Discovery for Alzheimer's Disease. In Animal and Translational Models for CNS Drug Discovery. Volume 2: Neurological Disorders. Edited by McArthur R, Borsini F. San Diego: Academic Press; 2008:93-157.

4. Becker RE, Greig NH, Giacobini E: Why do so many drugs for Alzheimer's disease fail in development? Time for new methods and new practices? J Alzheimers Dis 2008, 15:303-325.

5. Huang Y, Mucke L: Alzheimer mechanisms and therapeutic strategies. Cell 2012, 148:1204-1222.

6. Palop JJ, Chin J, Mucke L: A network dysfunction perspective on neurodegenerative diseases. Nature 2006, 443:768-773.

7. Terry RD, Masliah E, Salmon DP, Butters N, DeTeresa R, Hill R, Hansen LA, Katzman R: Physical basis of cognitive alterations in Alzheimer's disease: synapse loss is the major correlate of cognitive impairment. Ann Neurol 1991, 30:572-580.

8. DeKosky ST, Scheff SW: Synapse loss in frontal cortex biopsies in Alzheimer's disease: correlation with cognitive severity. Ann Neurol 1990 27:457-464
9. Pievani M, de Haan W, Wu T, Seeley WW, Frisoni GB: Functional network disruption in the degenerative dementias. Lancet Neurol 2011, 10:829-843.

10. Palop JJ, Mucke L: Amyloid-beta-induced neuronal dysfunction in Alzheimer's disease: from synapses toward neural networks. Nat Neurosci 2010, 13:812-818.

11. Giannakopoulos P, Herrmann FR, Bussiere T, Bouras C, Kovari E, Perl DP, Morrison JH, Gold G, Hof PR: Tangle and neuron numbers, but not amyloid load, predict cognitive status in Alzheimer's disease. Neurology 2003, 60:1495-1500.

12. Villemagne $V L$, Ataka S, Mizuno T, Brooks WS, Wada Y, Kondo M, Jones G, Watanabe $Y$, Mulligan $R$, Nakagawa $M$, et al: High striatal amyloid betapeptide deposition across different autosomal Alzheimer disease mutation types. Arch Neurol 2009, 66:1537-1544.

13. Furst AJ, Rabinovici GD, Rostomian AH, Steed T, Alkalay A, Racine C, Miller $\mathrm{BL}$, Jagust WJ: Cognition, glucose metabolism and amyloid burden in Alzheimer's disease. Neurobiol Aging 2012, 33:215-225.

14. Katzman R, Terry R, DeTeresa R, Brown T, Davies P, Fuld P, Renbing X, Peck A: Clinical, pathological, and neurochemical changes in dementia: a subgroup with preserved mental status and numerous neocortical plaques. Ann Neurol 1988, 23:138-144.

15. Tomlinson BE, Blessed $\mathrm{G}$, Roth M: Observations on the brains of non-demented old people. J Neurol Sci 1968, 7:331-356.

16. Davis DG, Schmitt FA, Wekstein DR, Markesbery WR: Alzheimer neuropathologic alterations in aged cognitively normal subjects. J Neuropathol Exp Neurol 1999, 58:376-388.

17. Crystal HA, Dickson DW, Sliwinski MJ, Lipton RB, Grober E, Marks-Nelson H, Antis P: Pathological markers associated with normal aging and dementia in the elderly. Ann Neurol 1993, 34:566-573.

18. Meyer-Luehmann M, Spires-Jones TL, Prada C, Garcia-Alloza M, de Calignon A, Rozkalne A, Koenigsknecht-Talboo J, Holtzman DM, Bacskai BJ, Hyman BT: Rapid appearance and local toxicity of amyloid-beta plaques in a mouse model of Alzheimer's disease. Nature 2008, 451:720-724.

19. Meyer-Luehmann M, Mielke M, Spires-Jones TL, Stoothoff W, Jones P, Bacskai BJ, Hyman BT: A reporter of local dendritic translocation shows plaque- related loss of neural system function in APP-transgenic mice. J Neurosci 2009, 29:12636-12640.

20. Spires-Jones TL, Kopeikina KJ, Koffie RM, de Calignon A, Hyman BT: Are tangles as toxic as they look? J Mol Neurosci 2011, 45:438-444.

21. Mucke L, Masliah E, Yu GQ, Mallory M, Rockenstein EM, Tatsuno G, Hu K, Kholodenko D, Johnson-Wood K, McConlogue L: High-level neuronal expression of abeta 1-42 in wild-type human amyloid protein precursor transgenic mice: synaptotoxicity without plaque formation. J Neurosci 2000, 20:4050-4058.

22. Klein WL, Krafft GA, Finch CE: Targeting small Abeta oligomers: the solution to an Alzheimer's disease conundrum? Trends Neurosci 2001, 24:219-224.

23. Oddo S, Caccamo A, Shepherd JD, Murphy MP, Golde TE, Kayed R, Metherate R, Mattson MP, Akbari Y, LaFerla FM: Triple-transgenic model of Alzheimer's disease with plaques and tangles: intracellular Abeta and synaptic dysfunction. Neuron 2003, 39:409-421.

24. Santacruz K, Lewis J, Spires T, Paulson J, Kotilinek L, Ingelsson M, Guimaraes A, DeTure M, Ramsden M, McGowan E, et al: Tau suppression in a neurodegenerative mouse model improves memory function. Science 2005, 309:476-481.

25. Haroutunian V, Purohit DP, Perl DP, Marin D, Khan K, Lantz M, Davis KL, Mohs RC: Neurofibrillary tangles in nondemented elderly subjects and mild Alzheimer disease. Arch Neurol 1999, 56:713-718.

26. O'Leary JC 3rd, Li Q, Marinec P, Blair L, Congdon EE, Johnson AG, Jinwal UK, Koren J 3rd, Jones JR, Kraft C, et al: Phenothiazine-mediated rescue of cognition in tau transgenic mice requires neuroprotection and reduced soluble tau burden. Mol Neurodegener 2010, 5:45.

27. Sydow A, Van der Jeugd A, Zheng F, Ahmed T, Balschun D, Petrova O, Drexler D, Zhou L, Rune G, Mandelkow E, et al: Tau-induced defects in synaptic plasticity, learning, and memory are reversible in transgenic mice after switching off the toxic Tau mutant. J Neurosci 2011, 31:2511-2525.

28. Morris M, Maeda S, Vossel K, Mucke L: The many faces of tau. Neuron 2011, 70:410-426.

29. Yaffe K, Barnes E: Chapter 9: Epidemiology and risk factors. In The Behavioral Neurology of Dementia. Edited by Miller BL, Boeve BF. New York: Cambridge University Press; 2009. 
30. Bertram L, Lill CM, Tanzi RE: The genetics of Alzheimer disease: back to the future. Neuron 2010, 68:270-281.

31. Corder EH, Saunders AM, Strittmatter WJ, Schmechel DE, Gaskell PC, Small GW, Roses AD, Haines JL, Pericak-Vance MA: Gene dose of apolipoprotein E type 4 allele and the risk of Alzheimer's disease in late onset families. Science 1993, 261:921-923.

32. Farrer LA, Cupples LA, Haines JL, Hyman B, Kukull WA, Mayeux R, Myers RH, Pericak-Vance MA, Risch N, van Duijn CM: Effects of age, sex, and ethnicity on the association between apolipoprotein E genotype and Alzheimer disease. A meta-analysis. APOE and Alzheimer Disease Meta Analysis Consortium. JAMA 1997, 278:1349-1356.

33. Genin $\mathrm{E}$, Hannequin $\mathrm{D}$, Wallon $\mathrm{D}$, Sleegers $\mathrm{K}$, Hiltunen $\mathrm{M}$, Combarros $\mathrm{O}$, Bullido MJ, Engelborghs S, De Deyn P, Berr C, et al: APOE and Alzheimer disease: a major gene with semi-dominant inheritance. Mol Psychiatry 2011, 16:903-907.

34. Logue MW, Schu M, Vardarajan BN, Buros J, Green RC, Go RC, Griffith P, Obisesan TO, Shatz R, Borenstein A, et al: A comprehensive genetic association study of Alzheimer disease in African Americans. Arch Neurol 2011, 68:1569-1579.

35. Jonsson T, Atwal JK, Steinberg S, Snaedal J, Jonsson PV, Bjornsson S, Stefansson H, Sulem P, Gudbjartsson D, Maloney J, et al: A mutation in APP protects against Alzheimer's disease and age-related cognitive decline. Nature 2012,

36. Tanzi RE, Bertram L: Twenty years of the Alzheimer's disease amyloid hypothesis: a genetic perspective. Cell 2005, 120:545-555.

37. Li S, Jin M, Koeglsperger T, Shepardson NE, Shankar GM, Selkoe DJ: Soluble Abeta oligomers inhibit long-term potentiation through a mechanism involving excessive activation of extrasynaptic NR2B-containing NMDA receptors. J Neurosci 2011, 31:6627-6638.

38. Yu W, Lu B: Synapses and dendritic spines as pathogenic targets in Alzheimer's disease. Neural Plast 2012, 2012:247150

39. Zempel $H$, Thies E, Mandelkow E, Mandelkow EM: Abeta oligomers cause localized $\mathrm{Ca}(2+)$ elevation, missorting of endogenous Tau into dendrites, Tau phosphorylation, and destruction of microtubules and spines. J Neurosci 2010, 30:11938-11950.

40. Palop JJ, Mucke L: Synaptic depression and aberrant excitatory network activity in Alzheimer's disease: two faces of the same coin? Neuromolecular Med 2010, 12:48-55.

41. Claus JJ, van Gool WA, Teunisse S, Walstra GJ, Kwa VI, Hijdra A, Verbeeten B Jr, Koelman JH, Bour $\amalg$, Ongerboer De Visser BW: Predicting survival in patients with early Alzheimer's disease. Dement Geriatr Cogn Disord 1998, 9:284-293.

42. Ueki A, Shinjo H, Shimode H, Nakajima T, Morita Y: Factors associated with mortality in patients with early-onset Alzheimer's disease: a five-year longitudinal study. Int I Geriatr Psychiatry 2001, 16:810-815.

43. Heyman A, Wilkinson WE, Hurwitz BJ, Helms MJ, Haynes CS, Utley CM, Gwyther LP: Early-onset Alzheimer's disease: clinical predictors of institutionalization and death. Neurology 1987, 37:980-984

44. Stern Y, Tang MX, Albert MS, Brandt J, Jacobs DM, Bell K, Marder K, Sano M, Devanand $D$, Albert $S M$, et al: Predicting time to nursing home care and death in individuals with Alzheimer disease. JAMA 1997, 277:806-812.

45. Lapane KL, Gambassi G, Landi F, Sgadari A, Mor V, Bernabei R: Gender differences in predictors of mortality in nursing home residents with AD. Neurology 2001, 56:650-654.

46. Hebert $L E$, Scherr PA, McCann JJ, Beckett LA, Evans DA: Is the risk of developing Alzheimer's disease greater for women than for men? Am J Epidemiol 2001, 153:132-136.

47. Petersen RC, Roberts RO, Knopman DS, Geda YE, Cha RH, Pankratz VS, Boeve BF, Tangalos EG, Ivnik RJ, Rocca WA: Prevalence of mild cognitive impairment is higher in men. The Mayo Clinic Study of Aging. Neurology 2010, 75:889-897.

48. Ganguli M, Dodge HH, Shen C, DeKosky ST: Mild cognitive impairment, amnestic type: an epidemiologic study. Neurology 2004, 63:115-121.

49. Koivisto K, Reinikainen KJ, Hanninen T, Vanhanen M, Helkala EL, Mykkanen L, Laakso M, Pyorala K, Riekkinen PJ Sr: Prevalence of age-associated memory impairment in a randomly selected population from eastern Finland. Neurology 1995, 45:741-747.

50. Luck T, Luppa M, Briel S, Matschinger H, Konig HH, Bleich S, Villringer A, Angermeyer MC, Riedel-Heller SG: Mild cognitive impairment: incidence and risk factors: results of the leipzig longitudinal study of the aged. J Am Geriatr Soc 2010, 58:1903-1910.

51. Kivipelto M, Helkala EL, Hanninen T, Laakso MP, Hallikainen M, Alhainen K, Soininen $\mathrm{H}$, Tuomilehto J, Nissinen A: Midlife vascular risk factors and late-life mild cognitive impairment: a population-based study. Neurology 2001, 56:1683-1689.

52. Jorm AF, Jolley D: The incidence of dementia: a meta-analysis. Neurology 1998, 51:728-733.

53. Roberts RO, Geda YE, Knopman DS, Cha RH, Pankratz VS, Boeve BF, Tangalos $E G$, Ivnik RJ, Rocca WA, Petersen RC: The incidence of $M C l$ differs by subtype and is higher in men: the Mayo Clinic Study of Aging. Neurology 2012, 78:342-351.

54. Hui JS, Wilson RS, Bennett DA, Bienias JL, Gilley DW, Evans DA: Rate of cognitive decline and mortality in Alzheimer's disease. Neurology 2003, 61:1356-1361

55. Caracciolo B, Palmer K, Monastero R, Winblad B, Backman L, Fratiglioni L: Occurrence of cognitive impairment and dementia in the community: a 9-year-long prospective study. Neurology 2008, 70:1778-1785.

56. Chakravarti S, Collins WP, Forecast JD, Newton JR, Oram DH, Studd JW: Hormonal profiles after the menopause. Br Med J 1976, 2:784-787.

57. Veldhuis JD: Aging and hormones of the hypothalamo-pituitary axis: gonadotropic axis in men and somatotropic axes in men and women. Ageing Res Rev 2008, 7:189-208.

58. Ferrini RL, Barrett-Connor E: Sex hormones and age: a cross-sectional study of testosterone and estradiol and their bioavailable fractions in community-dwelling men. Am J Epidemiol 1998, 147:750-754.

59. Merry BJ, Holehan AM: Aging of the Female Reproductive System: The Menopause. In Physiological Basis of Aging and Geriatrics. 2nd edition. Edited by Timiras PS. Boca Raton: CRC Press, Inc; 1994:147-170.

60. Morley JE, Kaiser F, Raum WJ, Perry HM 3rd, Flood JF, Jensen J, Silver AJ, Roberts E: Potentially predictive and manipulable blood serum correlates of aging in the healthy human male: progressive decreases in bioavailable testosterone, dehydroepiandrosterone sulfate, and the ratio of insulin-like growth factor 1 to growth hormone. Proc Natl Acad Sci U S A 1997, 94:7537-7542.

61. Nelson JF, Latham KR, Finch CE: Plasma testosterone levels in C57BL/6 male mice: effects of age and disease. Acta Endocrinol (Copenh) 1975, 80:744-752.

62. Nelson JF, Felicio LS, Osterburg HH, Finch CE: Differential contributions of ovarian and extraovarian factors to age-related reductions in plasma estradiol and progesterone during the estrous cycle of C57BL/6J mice. Endocrinology 1992, 130:805-810.

63. Finch CE, Jonec V, Wisner JR Jr, Sinha YN, de Vellis JS, Swerdloff RS: Hormone production by the pituitary and testes of male C57BL/6J mice during aging. Endocrinology 1977, 101:1310-1317.

64. Eleftheriou BE, Lucas LA: Age-related changes in testes, seminal vesicles and plasma testosterone levels in male mice. Gerontologia 1974, 20:231-238.

65. Shumaker SA, Legault C, Rapp SR, Thal L, Wallace RB, Ockene JK, Hendrix SL, Jones BN 3rd, Assaf AR, Jackson RD, et al: Estrogen plus progestin and the incidence of dementia and mild cognitive impairment in postmenopausal women: the Women's Health Initiative Memory Study: a randomized controlled trial. JAMA 2003, 289:2651-2662.

66. Shumaker SA, Legault C, Kuller L, Rapp SR, Thal L, Lane DS, Fillit H, Stefanick $M L$, Hendrix SL, Lewis $C E$, et al: Conjugated equine estrogens and incidence of probable dementia and mild cognitive impairment in postmenopausal women: Women's Health Initiative Memory Study. JAMA 2004, 291:2947-2958.

67. Grady D, Yaffe K, Kristof M, Lin F, Richards C, Barrett-Connor E: Effect of postmenopausal hormone therapy on cognitive function: the heart and estrogen/progestin replacement study. Am J Med 2002, 113:543-548.

68. Mulnard RA, Cotman CW, Kawas C, van Dyck CH, Sano M, Doody R, Koss E, Pfeiffer E, Jin S, Gamst A, et al: Estrogen replacement therapy for treatment of mild to moderate Alzheimer disease: a randomized controlled trial. Alzheimer's Disease Cooperative Study. JAMA 2000, 283:1007-1015.

69. Henderson WW, Paganini-Hill A, Miller BL, Elble RJ, Reyes PF, Shoupe D, McCleary CA, Klein RA, Hake AM, Farlow MR: Estrogen for Alzheimer's disease in women: randomized, double-blind, placebo-controlled trial. Neurology 2000, 54:295-301.

70. Wang PN, Liao SQ, Liu RS, Liu CY, Chao HT, Lu SR, Yu HY, Wang SJ, Liu HC: Effects of estrogen on cognition, mood, and cerebral blood flow in AD: a controlled study. Neurology 2000, 54:2061-2066.

71. Wise PM, Suzuki S, Brown CM: Estradiol: a hormone with diverse and contradictory neuroprotective actions. Dialogues Clin Neurosci 2009, 11:297-303. 
72. Turgeon JL, McDonnell DP, Martin KA, Wise PM: Hormone therapy: physiological complexity belies therapeutic simplicity. Science 2004, 304:1269-1273.

73. Harman SM, Brinton EA, Cedars M, Lobo R, Manson JE, Merriam GR, Miller VM, Naftolin F, Santoro N: KEEPS: the Kronos Early Estrogen Prevention Study. Climacteric 2005, 8:3-12.

74. Golde TE, Schneider LS, Koo EH: Anti-abeta therapeutics in Alzheimer's disease: the need for a paradigm shift. Neuron 2011, 69:203-213.

75. Jack CR Jr, Knopman DS, Jagust WJ, Shaw LM, Aisen PS, Weiner MW, Petersen RC, Trojanowski JQ: Hypothetical model of dynamic biomarkers of the Alzheimer's pathological cascade. Lancet Neurol 2010, 9:119-128.

76. Feldman HA, Longcope C, Derby CA, Johannes CB, Araujo AB, Coviello $A D$, Bremner WJ, McKinlay JB: Age trends in the level of serum testosterone and other hormones in middle-aged men: longitudinal results from the Massachusetts male aging study. J Clin Endocrinol Metabol 2002, 87:589-598.

77. Harman SM, Metter EJ, Tobin JD, Pearson J, Blackman MR: Longitudinal effects of aging on serum total and free testosterone levels in healthy men. Baltimore Longitudinal Study of Aging. J Clin Endocrinol Metabol 2001, 86:724-731.

78. Morley JE, Kaiser FE, Perry HM 3rd, Patrick P, Morley PM, Stauber PM, Vellas B, Baumgartner RN, Garry PJ: Longitudinal changes in testosterone, luteinizing hormone, and follicle-stimulating hormone in healthy older men. Metabolism: clinical and experimental 1997, 46:410-413.

79. Liu PY, Beilin J, Meier C, Nguyen TV, Center JR, Leedman PJ, Seibel MJ, Eisman JA, Handelsman DJ: Age-related changes in serum testosterone and sex hormone binding globulin in Australian men: longitudinal analyses of two geographically separate regional cohorts. J Clin Endocrinol Metabol 2007, 92:3599-3603.

80. Hammond GL: Access of reproductive steroids to target tissues. Obstet Gynecol Clin North Am 2002, 29:411-423.

81. Hammond GL: Diverse roles for sex hormone-binding globulin in reproduction. Biol Reprod 2011, 85:431-441.

82. Muller M, Schupf N, Manly JJ, Mayeux R, Luchsinger JA: Sex hormone binding globulin and incident Alzheimer's disease in elderly men and women. Neurobiol Aging 2010, 31:1758-1765.

83. Hoskin EK, Tang MX, Manly JJ, Mayeux R: Elevated sex-hormone binding globulin in elderly women with Alzheimer's disease. Neurobiol Aging 2004, 25:141-147.

84. Paoletti AM, Congia S, Lello S, Tedde D, Orru M, Pistis M, Pilloni M, Zedda P, Loddo A, Melis GB: Low androgenization index in elderly women and elderly men with Alzheimer's disease. Neurology 2004, 62:301-303.

85. Rosario ER, Pike CJ: Androgen regulation of beta-amyloid protein and the risk of Alzheimer's disease. Brain Res Rev 2008, 57:444-453.

86. Fitzgerald $\mathrm{C}$, Zimon $\mathrm{AE}$, Jones $\mathrm{EE}$ : Aging and reproductive potential in women. Yale J Biol Med 1998, 71:367-381.

87. Downs $\lrcorner$, Wise PM: The role of the brain in female reproductive aging. Mol Cell Endocrinol 2009, 299:32-38.

88. Kermath BA, Gore AC: Neuroendocrine control of the transition to reproductive senescence: lessons learned from the female rodent model. Neuroendocrinology 2012, 96:1-12.

89. Mobbs CV, Gee DM, Finch CE: Reproductive senescence in female C57BL/6J mice: ovarian impairments and neuroendocrine impairments that are partially reversible and delayable by ovariectomy. Endocrinology 1984, 115:1653-1662.

90. Mayer LP, Devine PJ, Dyer CA, Hoyer PB: The follicle-deplete mouse ovary produces androgen. Biol Reprod 2004, 71:130-138.

91. Arnold AP, Chen X: What does the "four core genotypes" mouse model tell us about sex differences in the brain and other tissues? Front Neuroendocrinol 2009, 30:1-9.

92. McCarthy MM, Arnold AP, Ball GF, Blaustein JD, De Vries GJ: Sex differences in the brain: the not so inconvenient truth. J Neurosci 2012, 32:2241-2247.

93. Baker HW, Burger HG, de Kretser DM, Hudson B, O'Connor S, Wang C, Mirovics A, Court J, Dunlop M, Rennie GC: Changes in the pituitarytesticular system with age. Clin Endocrinol (Oxf) 1976, 5:349-372.

94. Hale GE, Burger HG: Hormonal changes and biomarkers in late reproductive age, menopausal transition and menopause. Best Pract Res Clin Obstet Gynaecol 2009, 23:7-23.

95. Ostergard DR, Parlow AF, Townsend DE: Acute effect of castration on serum FSH and LH in the adult woman. J Clin Endocrinol Metabol 1970, 31:43-47.
96. Monroe SE, Jaffee RB, Midgley AJ: Regulation of human gonadotropins: 13. Changes in serum gonadotropins in menstruating women in response to oophorectomy. J Clin Endocrinol 1972, 34:420-422.

97. Naik SI, Young LS, Charlton HM, Clayton RN: Pituitary gonadotropinreleasing hormone receptor regulation in mice. II: Females. Endocrinology 1984, 115:114-120

98. Naik SI, Young LS, Charlton HM, Clayton RN: Pituitary gonadotropinreleasing hormone receptor regulation in mice. I: Males. Endocrinology 1984, 115:106-113.

99. Danilovich N, Babu PS, Xing W, Gerdes M, Krishnamurthy H, Sairam MR: Estrogen deficiency, obesity, and skeletal abnormalities in follicle-stimulating hormone receptor knockout (FORKO) female mice. Endocrinology 2000, 141:4295-4308.

100. Danilovich N, Maysinger D, Sairam MR: Perspectives on reproductive senescence and biological aging: studies in genetically altered follitropin receptor knockout [FORKO] mice. Exp Gerontol 2004, 39:1669-1678.

101. Jucker M: The benefits and limitations of animal models for translational research in neurodegenerative diseases. Nat Med 2010, 16:1210-1214.

102. Ashe KH, Zahs KR: Probing the biology of Alzheimer's disease in mice. Neuron 2010, 66:631-645.

103. Roberson ED: Contemporary approaches to Alzheimer's disease and frontotemporal dementia. Methods Mol Biol 2011, 670:1-9.

104. Hoe HS, Lee HK, Pak DT: The upside of APP at synapses. CNS Neurosci Ther 2012, 18:47-56.

105. Lazarov O, Demars MP: All in the Family: how the APPs Regulate Neurogenesis. Front Neurosci 2012, 6:81.

106. Reaume AG, Howland DS, Trusko SP, Savage MJ, Lang DM, Greenberg BD, Siman R, Scott RW: Enhanced amyloidogenic processing of the beta-amyloid precursor protein in gene-targeted mice bearing the Swedish familial Alzheimer's disease mutations and a "humanized" Abeta sequence. J Biol Chem 1996, 271:23380-23388.

107. Flood DG, Reaume AG, Dorfman KS, Lin YG, Lang DM, Trusko SP, Savage MJ, Annaert WG, De Strooper B, Siman R, Scott RW: FAD mutant PS-1 genetargeted mice: increased A beta 42 and A beta deposition without APP overproduction. Neurobiol Aging 2002, 23:335-348.

108. Malthankar-Phatak GH, Lin YG, Giovannone N, Siman R: Amyloid deposition and advanced age fails to induce Alzheimer's type progression in a double knock-in mouse model. Aging dis 2012, 3:141-155.

109. Morris RG: Episodic-like memory in animals: psychological criteria, neural mechanisms and the value of episodic-like tasks to investigate animal models of neurodegenerative disease. Philos Trans R Soc Lond B Biol Sci 2001, 356:1453-1465.

110. Maguire JL, Stell BM, Rafizadeh M, Mody I: Ovarian cycle-linked changes in $G A B A(A)$ receptors mediating tonic inhibition alter seizure susceptibility and anxiety. Nat Neurosci 2005, 8:797-804.

111. Fata JE, Chaudhary V, Khokha R: Cellular turnover in the mammary gland is correlated with systemic levels of progesterone and not 17beta-estradiol during the estrous cycle. Biol Reprod 2001, 65:680-688.

112. Walmer DK, Wrona MA, Hughes CL, Nelson KG: Lactoferrin expression in the mouse reproductive tract during the natural estrous cycle: correlation with circulating estradiol and progesterone. Endocrinology 1992, 131:1458-1466.

113. Wood GA, Fata JE, Watson KL, Khokha R: Circulating hormones and estrous stage predict cellular and stromal remodeling in murine uterus. Reproduction 2007, 133:1035-1044.

114. Melnikova T, Savonenko A, Wang Q, Liang X, Hand T, Wu L, Kaufmann WE, Vehmas A, Andreasson Kl: Cycloxygenase-2 activity promotes cognitive deficits but not increased amyloid burden in a model of Alzheimer's disease in a sex-dimorphic pattern. Neuroscience 2006 141:1149-1162.

115. Clinton LK, Billings LM, Green KN, Caccamo A, Ngo J, Oddo S, McGaugh JL, LaFerla FM: Age-dependent sexual dimorphism in cognition and stress response in the 3xTg-AD mice. Neurobiol Dis 2007, 28:76-82.

116. Carroll JC, Rosario ER, Kreimer S, Villamagna A, Gentzschein E, Stanczyk FZ, Pike CJ: Sex differences in beta-amyloid accumulation in 3xTg-AD mice: role of neonatal sex steroid hormone exposure. Brain Res 2010, 1366:233-245

117. Pietropaolo S, Sun Y, Li R, Brana C, Feldon J, Yee BK: The impact of voluntary exercise on mental health in rodents: a neuroplasticity perspective. Behav Brain Res 2008, 192:42-60.

118. Gimenez-Llort L, Garcia Y, Buccieri K, Revilla S, Sunol C, Cristofol R, Sanfeliu C: Gender-specific neuroimmunoendocrine response to 
treadmill exercise in 3xTg-AD Mice. Int J Alzheimers Dis 2010, 2010:128354.

119. King DL, Arendash GW, Crawford F, Sterk T, Menendez J, Mullan MJ: Progressive and gender-dependent cognitive impairment in the APP (SW) transgenic mouse model for Alzheimer's disease. Behav Brain Res 1999, 103:145-162

120. Gimenez-Llort L, Arranz L, Mate I, De la Fuente M: Gender-specific neuroimmunoendocrine aging in a triple-transgenic 3xTg-AD mouse model for Alzheimer's disease and its relation with longevity. Neuroimmunomodulation 2008, 15:331-343.

121. Howlett DR, Richardson JC, Austin A, Parsons AA, Bate ST, Davies DC, Gonzalez Ml: Cognitive correlates of Abeta deposition in male and female mice bearing amyloid precursor protein and presenilin-1 mutant transgenes. Brain Res 2004, 1017:130-136.

122. O'Leary TP, Brown RE: Visuo-spatial learning and memory deficits on the Barnes maze in the 16-month-old APPswe/PS1dE9 mouse model of Alzheimer's disease. Behav Brain Res 2009, 201:120-127.

123. Hirata-Fukae C, Li HF, Hoe HS, Gray AJ, Minami SS, Hamada K, Niikura T, Hua F, Tsukagoshi-Nagai H, Horikoshi-Sakuraba Y, et al: Females exhibit more extensive amyloid, but not tau, pathology in an Alzheimer transgenic model. Brain Res 2008, 1216:92-103.

124. Callahan MJ, Lipinski WJ, Bian F, Durham RA, Pack A, Walker LC: Augmented senile plaque load in aged female beta-amyloid precursor proteintransgenic mice. Am J Pathol 2001, 158:1173-1177.

125. Schafer S, Wirths O, Multhaup G, Bayer TA: Gender dependent APP processing in a transgenic mouse model of Alzheimer's disease. I Neural Transm 2007, 114:387-394.

126. Wang J, Tanila H, Puolivali J, Kadish I, van Groen T: Gender differences in the amount and deposition of amyloidbeta in APPswe and PS1 double transgenic mice. Neurobiol Dis 2003, 14:318-327.

127. Pistell PJ, Zhu M, Ingram DK: Acquisition of conditioned taste aversion is impaired in the amyloid precursor protein/presenilin 1 mouse model of Alzheimer's disease. Neuroscience 2008, 152:594-600.

128. Perez SE, Berg BM, Moore KA, He B, Counts SE, Fritz JJ, Hu YS, Lazarov O, Lah JJ, Mufson EJ: DHA diet reduces AD pathology in young APPswe/PS1 Delta E9 transgenic mice: possible gender effects. J Neurosci Res 2010, 88:1026-1040

129. Lin J, Li X, Yuan F, Lin L, Cook CL, Rao CV, Lei Z: Genetic ablation of luteinizing hormone receptor improves the amyloid pathology in a mouse model of Alzheimer disease. J Neuropathol Exp Neurol 2010, 69:253-261.

130. Schuessel K, Schafer S, Bayer TA, Czech C, Pradier L, Muller-Spahn F, Muller WE, Eckert A: Impaired Cu/Zn-SOD activity contributes to increased oxidative damage in APP transgenic mice. Neurobiol Dis 2005, 18:89-99.

131. Minami SS, Sidahmed E, Aid S, Shimoji M, Niikura T, Mocchetti I, Rebeck GW, Prendergast JS, Dealwis $C$, Wetzel R, et al: Therapeutic versus neuroinflammatory effects of passive immunization is dependent on Abeta/amyloid burden in a transgenic mouse model of Alzheimer's disease. J Neuroinflammation 2010, 7:57.

132. Oliveira SM, Ribeiro CA, Cardoso I, Saraiva MJ: Gender-dependent transthyretin modulation of brain amyloid-beta levels: evidence from a mouse model of Alzheimer's disease. J Alzheimers Dis 2011, 27:429-439.

133. Pacheco-Quinto J, de Turco EB R, DeRosa S, Howard A, Cruz-Sanchez F, Sambamurti K, Refolo L, Petanceska S, Pappolla MA Hyperhomocysteinemic Alzheimer's mouse model of amyloidosis shows increased brain amyloid beta peptide levels. Neurobiol Dis 2006 22:651-656.

134. Park IH, Hwang EM, Hong HS, Boo JH, Oh SS, Lee J, Jung MW, Bang OY, Kim SU, Mook-Jung I: Lovastatin enhances Abeta production and senile plaque deposition in female Tg2576 mice. Neurobiol Aging 2003, 24:637-643.

135. Touma C, Ambree O, Gortz N, Keyvani K, Lewejohann L, Palme R, Paulus W, Schwarze-Eicker K, Sachser N: Age- and sex-dependent development of adrenocortical hyperactivity in a transgenic mouse model of Alzheimer's disease. Neurobiol Aging 2004, 25:893-904

136. Overk CR, Lu PY, Wang YT, Choi J, Shaw JW, Thatcher GR, Mufson EJ: Effects of aromatase inhibition versus gonadectomy on hippocampal complex amyloid pathology in triple transgenic mice. Neurobiol Dis 2012, 45:479-487

137. Devi L, Alldred MJ, Ginsberg SD, Ohno M: Sex- and brain region-specific acceleration of beta-amyloidogenesis following behavioral stress in a mouse model of Alzheimer's disease. Mol Brain 2010, 3:34.
138. Lee JY, Cole TB, Palmiter RD, Suh SW, Koh JY: Contribution by synaptic zinc to the gender-disparate plaque formation in human Swedish mutant APP transgenic mice. Proc Natl Acad Sci U S A 2002, 99:7705-7710.

139. Oikawa N, Ogino K, Masumoto T, Yamaguchi H, Yanagisawa K: Gender effect on the accumulation of hyperphosphorylated tau in the brain of locusceruleus-injured APP-transgenic mouse. Neurosci Lett 2010, 468:243-247.

140. Maynard CJ, Cappai R, Volitakis I, Cherny RA, Masters CL, Li QX, Bush Al: Gender and genetic background effects on brain metal levels in APP transgenic and normal mice: implications for Alzheimer beta-amyloid pathology. J Inorg Biochem 2006, 100:952-962.

141. Nakashima AS, Oddo S, Laferla FM, Dyck RH: Experience-dependent regulation of vesicular zinc in male and female $3 \times \mathrm{Tg}-\mathrm{AD}$ mice. Neurobiol Aging 2010, 31:605-613.

142. Barrier L, Ingrand S, Fauconneau B, Page G: Gender-dependent accumulation of ceramides in the cerebral cortex of the APP(SL)/PS1 Ki mouse model of Alzheimer's disease. Neurobiol Aging 2010, 31:1843-1853.

143. Ash ES, Alavijeh MS, Palmer AM, Mitchelmore C, Howlett DR, Francis PT, Broadstock M, Richardson JC: Neurochemical changes in a double transgenic mouse model of Alzheimer's disease fed a pro-oxidant diet. Neurochem Int 2010, 57:504-511.

144. Hsiao KK, Borchelt DR, Olson K, Johannsdottir R, Kitt C, Yunis W, Xu S, Eckman C, Younkin S, Price D, et al: Age-related CNS disorder and early death in transgenic FVB/N mice overexpressing Alzheimer amyloid precursor proteins. Neuron 1995, 15:1203-1218.

145. Palop JJ, Chin J, Roberson ED, Wang J, Thwin MT, Bien-Ly N, Yoo J, Ho KO, Yu GQ, Kreitzer A, et al: Aberrant excitatory neuronal activity and compensatory remodeling of inhibitory hippocampal circuits in mouse models of Alzheimer's disease. Neuron 2007, 55:697-711.

146. Roberson ED, Scearce-Levie K, Palop JJ, Yan F, Cheng IH, Wu T, Gerstein $H$, Yu GQ, Mucke L: Reducing endogenous tau ameliorates amyloid betainduced deficits in an Alzheimer's disease mouse model. Science 2007 316:750-754.

147. Roberson ED, Halabisky B, Yoo JW, Yao J, Chin J, Yan F, Wu T, Hamto P, Devidze N, Yu GQ, et al: Amyloid-beta/Fyn-induced synaptic, network, and cognitive impairments depend on tau levels in multiple mouse models of Alzheimer's disease. J Neurosci 2011, 31:700-711.

148. Minkeviciene R, Rheims S, Dobszay MB, Zilberter M, Hartikainen J, Fulop L, Penke B, Zilberter Y, Harkany T, Pitkanen A, Tanila H: Amyloid beta-induced neuronal hyperexcitability triggers progressive epilepsy. J Neurosci 2009, 29:3453-3462

149. Ittner LM, Ke YD, Delerue F, Bi M, Gladbach A, van Eersel J, Wolfing H, Chieng BC, Christie MJ, Napier IA, et al: Dendritic function of tau mediates amyloid-beta toxicity in Alzheimer's disease mouse models. Cell 2010 142:387-397.

150. Verret L, Mann EO, Hang GB, Barth AM, Cobos I, Ho K, Devidze N, Masliah E Kreitzer AC, Mody I, et al: Inhibitory interneuron deficit links altered network activity and cognitive dysfunction in Alzheimer model. Cell 2012, 149:708-721.

151. Woolley CS: Acute effects of estrogen on neuronal physiology. Annu Rev Pharmacol Toxicol 2007, 47:657-680.

152. Spencer JL, Waters EM, Romeo RD, Wood GE, Milner TA, McEwen BS: Uncovering the mechanisms of estrogen effects on hippocampal function. Front Neuroendocrinol 2008, 29:219-237.

153. Foy MR, Baudry M, Diaz Brinton R, Thompson RF: Estrogen and hippocampal plasticity in rodent models. J Alzheimers Dis 2008, 15:589-603.

154. Brinton RD, Thompson RF, Foy MR, Baudry M, Wang J, Finch CE, Morgan TE, Pike CJ, Mack WJ, Stanczyk FZ, Nilsen J: Progesterone receptors: form and function in brain. Front Neuroendocrinol 2008, 29:313-339.

155. Holland J, Bandelow S, Hogervorst E: Testosterone levels and cognition in elderly men: a review. Maturitas 2011, 69:322-337.

156. Pike CJ, Nguyen TV, Ramsden M, Yao M, Murphy MP, Rosario ER: Androgen cell signaling pathways involved in neuroprotective actions. Horm Behav 2008, 53:693-705.

157. Frye CA: Neurosteroids' effects and mechanisms for social, cognitive, emotional, and physical functions. Psychoneuroendocrinology 2009, 34(Suppl 1):S143-161.

158. Wang JM, Liu L, Irwin RW, Chen S, Brinton RD: Regenerative potential of allopregnanolone. Brain Res Rev 2008, 57:398-409.

159. Heikkinen T, Kalesnykas G, Rissanen A, Tapiola T, livonen S, Wang J, Chaudhuri J, Tanila H, Miettinen R, Puolivali J: Estrogen treatment improves spatial learning in APP + PS1 mice but does not affect beta amyloid accumulation and plaque formation. Exp Neurol 2004, 187:105-117. 
160. Golub MS, Germann SL, Mercer M, Gordon MN, Morgan DG, Mayer LP, Hoyer PB: Behavioral consequences of ovarian atrophy and estrogen replacement in the APPswe mouse. Neurobiol Aging 2008, 29:1512-1523.

161. Levin-Allerhand JA, Lominska CE, Wang J, Smith JD: 17Alpha-estradiol and 17beta-estradiol treatments are effective in lowering cerebral amyloid-beta levels in AbetaPPSWE transgenic mice. J Alzheimers Dis 2002, 4:449-457.

162. Carroll JC, Pike CJ: Selective estrogen receptor modulators differentially regulate Alzheimer-like changes in female 3xTg-AD mice. Endocrinology 2008, 149:2607-2611.

163. Carroll JC, Rosario ER, Chang L, Stanczyk FZ, Oddo S, LaFerla FM, Pike CJ: Progesterone and estrogen regulate Alzheimer-like neuropathology in female 3xTg-AD mice. J Neurosci 2007, 27:13357-13365.

164. Carroll JC, Rosario ER, Villamagna A, Pike CJ: Continuous and cyclic progesterone differentially interact with estradiol in the regulation of Alzheimer-like pathology in female 3xTransgenic-Alzheimer's disease mice. Endocrinology 2010, 151:2713-2722.

165. Zhao L, Yao J, Mao Z, Chen S, Wang Y, Brinton RD: 17beta-Estradiol regulates insulin-degrading enzyme expression via an ERbeta/PI3-K pathway in hippocampus: relevance to Alzheimer's prevention. Neurobiol Aging 2011, 32:1949-1963.

166. Xu H, Wang R, Zhang YW, Zhang X: Estrogen, beta-amyloid metabolism/ trafficking, and Alzheimer's disease. Ann N Y Acad Sci 2006, 1089:324-342.

167. Zheng H, Xu H, Uljon SN, Gross R, Hardy K, Gaynor J, Lafrancois J, Simpkins J, Refolo LM, Petanceska S, et al: Modulation of A(beta) peptides by estrogen in mouse models. J Neurochem 2002, 80:191-196.

168. Amtul Z, Wang L, Westaway D, Rozmahel RF: Neuroprotective mechanism conferred by 17 beta-estradiol on the biochemical basis of Alzheimer's disease. Neuroscience 2010, 169:781-786.

169. Frye CA, Walf AA: Effects of progesterone administration and APPswe +PSEN1Deltae9 mutation for cognitive performance of mid-aged mice. Neurobiol Learn Mem 2008, 89:17-26.

170. Green PS, Bales K, Paul S, Bu G: Estrogen therapy fails to alter amyloid deposition in the PDAPP model of Alzheimer's disease. Endocrinology 2005, 146:2774-2781.

171. Yue X, Lu M, Lancaster T, Cao P, Honda S, Staufenbiel M, Harada N, Zhong Z, Shen Y, Li R: Brain estrogen deficiency accelerates Abeta plaque formation in an Alzheimer's disease animal model. Proc Natl Acad Sci U S A 2005, 102:19198-19203.

172. Levin-Allerhand JA, Smith JD: Ovariectomy of young mutant amyloid precursor protein transgenic mice leads to increased mortality. J Mol Neurosci 2002, 19:163-166.

173. Hogervorst E, Williams J, Budge M, Barnetson L, Combrinck M, Smith AD: Serum total testosterone is lower in men with Alzheimer's disease. Neuro Endocrinol Lett 2001, 22:163-168.

174. Moffat SD, Zonderman AB, Metter EJ, Kawas C, Blackman MR, Harman SM, Resnick SM: Free testosterone and risk for Alzheimer disease in older men. Neurology 2004, 62:188-193.

175. Rosario ER, Chang L, Stanczyk FZ, Pike CJ: Age-related testosterone depletion and the development of Alzheimer disease. JAMA 2004, 292:1431-1432.

176. Moffat SD: Does testosterone mediate cognitive decline in elderly men? J Gerontol A Biol Sci Med Sci 2006, 61:521.

177. Rosario ER, Carroll JC, Oddo S, LaFerla FM, Pike CJ: Androgens regulate the development of neuropathology in a triple transgenic mouse model of Alzheimer's disease. J Neurosci 2006, 26:13384-13389.

178. McAllister C, Long J, Bowers A, Walker A, Cao P, Honda S, Harada N, Staufenbiel M, Shen Y, Li R: Genetic targeting aromatase in male amyloid precursor protein transgenic mice down-regulates beta-secretase (BACE1) and prevents Alzheimer-like pathology and cognitive impairment. J Neurosci 2010, 30:7326-7334.

179. Rosario ER, Carroll J, Pike CJ: Testosterone regulation of Alzheimer-like neuropathology in male 3xTg-AD mice involves both estrogen and androgen pathways. Brain Res 2010, 1359:281-290.

180. Casadesus G, Webber KM, Atwood CS, Pappolla MA, Perry G, Bowen RL, Smith MA: Luteinizing hormone modulates cognition and amyloid-beta deposition in Alzheimer APP transgenic mice. Biochim Biophys Acta 2006 1762:447-452.

doi:10.1186/2042-6410-3-24

Cite this article as: Dubal et al.: Sex and gonadal hormones in mouse models of Alzheimer's disease: what is relevant to the human condition?. Biology of Sex Differences 2012 3:24.

\section{Submit your next manuscript to BioMed Central and take full advantage of:}

- Convenient online submission

- Thorough peer review

- No space constraints or color figure charges

- Immediate publication on acceptance

- Inclusion in PubMed, CAS, Scopus and Google Scholar

- Research which is freely available for redistribution 